\title{
Brazilian Theraphosidae: a toxicological point of view
}

Keven Wender Rodrigues Macedo ${ }^{1}$, Lucas Jeferson de Lima Costa ${ }^{1}$, Jéssica Oliveira de Souza ${ }^{1}$, Isadora Alves de Vasconcelos ${ }^{1}$, Jessica Schneider de Castro ${ }^{1}$, Carlos José Correia de Santana ${ }^{1,2}$ (1), Ana Carolina Martins Magalhães ${ }^{1}$, Mariana de Souza Castro ${ }^{1,2}$, Osmindo Rodrigues Pires Júnior ${ }^{1 *}$ (1)

${ }^{1}$ Laboratory of Toxinology, Department of Physiological Sciences, Institute of Biology, University of Brasília (UnB), Brasília, DF, Brazil.

${ }^{2}$ Laboratory of Biochemistry and Protein Chemistry, Department of Cell Biology, Institute of Biology, University of Brasília (UnB), Brasília, DF, Brazil.

\section{Keywords:}

Brazilian Theraphosidae

Crude venom

Hemocytes

Biological active

compounds

Spiders

\begin{abstract}
The Theraphosidae family includes the largest number of species of the Mygalomorphae infraorder, with hundreds of species currently catalogued. However, there is a huge lack on physiologic and even ecologic information available, especially in Brazil, which is the most biodiverse country in the world. Over the years, spiders have been presented as a source of multiple biologically active compounds with basic roles, such as primary defense against pathogenic microorganisms or modulation of metabolic pathways and as specialized hunters. Spider venoms also evolved in order to enable the capture of prey by interaction with a diversity of molecular targets of interest, raising their pharmaceutical potential for the development of new drugs. Among the activities found in compounds isolated from venoms and hemocytes of Brazilian Theraphosidae there are antimicrobial, antifungal, antiparasitic and antitumoral, as well as properties related to proteinase action and neuromuscular blockage modulated by ionic voltagegated channel interaction. These characteristics are present in different species from multiple genera, which is strong evidence of the important role in spider survival. The present review aims to compile the main results of studies from the last decades on Brazilian Theraphosidae with special focus on results obtained with the crude venom or compounds isolated from both venom and hemocytes, and their physiological and chemical characterization.
\end{abstract}

* Correspondence: osmindo@gmail.com or osmindo@unb.br https://doi.org/10.1590/1678-9199-JVATITD-2021-0004

Received: 18 January 2021; Accepted: 8 April 2021; Published online: 22 November 2021 


\section{Background}

Mygalomorphae (Pocock, 1892) is an infraorder of spiders, which includes species from the family Theraphosidae, commonly known as tarantulas. These spiders are characterized by medium to large size, characteristic articulated chelicerae that move parallel to the axis of the animal's body, called orthognathic chelicerae. Despite their size inspiring fear, Theraphosidae usually are not dangerous to humans [1]. This family is the largest within Mygalomorphae, including 1004 species distributed in 152 genera [2]. The updated number of Theraphosidae in Brazil is not available, with the last record accounting 185 species divided in 36 genera [3].

The main source of compounds isolated from spiders comes from the venom and hemocytes. The tarantula venom is extracted through electrical stimulation at the base of the chelicerae, forcing its contraction and provoking the venom release. To obtain the hemocytes, the spiders are cooled then an apyrogenic needle is used to perform a cardiac puncture for hemolymph extraction. To avoid the coagulation or degranulation of the hemocytes, the extraction is conducted in the presence of sodium citrate buffer. The hemocytes are separated from plasma by centrifugation $[4,5,6]$.

Tarantula venom has a complex composition, containing inorganic salts, nucleotides, free amino acids, polyamines, neurotransmitters, peptides and proteins. The venom generally acts on prey nervous system leading to paralysis due to the large number of neurotoxins as acylpolyamines and ion channel modifiers or pore-forming peptides $[1,7,8]$.

The diversity of biological activities from crude venom, hemocyte extracts or compounds isolated from both sources, arouse the interest of the scientific community and industries. Antimicrobial, neurotoxic, cytotoxic, hemolytic and protease activities have been described throughout the years, and the molecules responsible for these activities have shown themselves to be promising in the development of new products like pesticides or pharmaceuticals $[5,9,10]$.

In this review we present 43 studies performed with Brazilian Theraphosidae species along the last decades with focus on the structural and pharmacological characterization of biologically active compounds isolated from the venom or hemocytes of this family.

\section{Methods}

\section{Search strategy}

The selection of articles for this review was based on Preferred Reporting Items for Systematic Reviews and Meta Analyses (PRISMA) [11]. The search for articles was performed primarily in Google Scholar, followed by PubMed and ScienceDirect. The keywords for research were "Theraphosidae antimicrobial", "Theraphosidae antitumoral" and specific researches each Theraphosidae species/genera selected once their occurrence in Brazil was check and confirmed based on World Spider
Catalog (https://wsc.nmbe.ch/). Posteriorly were included "Theraphosidae venom", "Theraphosidae toxins", "Theraphosidae hemocytes", "Theraphosidae venom composition" once new relevant activities described were included to the original antimicrobial/antitumoral focus of this review.

\section{Study selection and data extraction}

The search on the 3 databases (Google Scholar = 1709; PubMed $=155$; ScienceDirect $=572$ ) resulted in a total of 2436, with 99 studies initially selected by title and abstract reading once they present information about venom and hemocytes compounds from Theraphosidae. References from studies with these inclusion criteria was check to include possible relevant articles.

Sixty-seven articles were selected for full reading and papers without the focus on venom or hemocytes compounds, duplicated or unrelated information and focused on spiders that do not occur in Brazil were excluded after reading. Some studies with multiple spiders were selected when at least one of the species presented in the study showed the inclusion criteria, but only the spiders with inclusion criteria have their related results described. No boolean operator was utilized in these steps, all articles were selected by two authors with a third author evaluating the quality and eligibility of the studies.

The search in Uniprot (www.uniprot.org) for sequenced compounds were performed with the advanced search tool. Genera and species (sp. when species is unknown) was utilized as keywords on the database, the search results is presented on Table 1 .

\section{Results and Discussion}

The complete flow chart with the description of the selection process is presented in Figure 1A. The search resulted in 43 articles selected to inclusion on the review, contemplating thirteen species (Fig. 1B). The oldest publication dates from 1997 and newest from 2021 (Fig. 1C). Although some articles have been excluded to full description, they were utilized for introduction and spider description.

\section{Theraphosa blondi}

Theraphosa blondi (Latreille, 1804; Fig. 2) commonly known as Goliath bird eater spider, is one of the largest known spiders, both in size and mass with above $30 \mathrm{~cm}$ leg spam [12]. It occurs in the Amazon rainforest, can be found in northern Brazil, Suriname, Guyana, French Guiana, and southern Venezuela. T. blondi is a terrestrial spider and lives in deep burrows, usually found in marshy or swampy areas $[12,13]$.

In 2002, Fontana et al. [14] studied the mode of action of $T$. blondi venom in mouse phrenic nerve-diaphragm preparation. The venom caused partial and reversible neuromuscular blockage, not depressing spasms caused by direct stimulation or altering the membrane potential. The blockage caused by the venom suffered a weak antagonistic effect by neostigmine, which however, completely blocked the venom activity in miniature 
Table 1. Uniprot register of toxins extracted from Brazilian Theraphosidae spiders.

\begin{tabular}{|c|c|c|c|c|c|}
\hline $\begin{array}{l}\text { Uniprot } \\
\text { entry }\end{array}$ & Entry name & Protein name & Source & Sequence & Reference \\
\hline P83745 & TX1_THEBL & к-theraphotoxin-Tb1a & $\begin{array}{l}\text { Theraphosa blondi } \\
\text { venom }\end{array}$ & $\begin{array}{l}\text { AACLGMFESCDPNNDKC } \\
\text { CPNRECNRKHKWCKYKLW }\end{array}$ & $\begin{array}{l}\text { Ebbinghaus } \\
\text { et al. [15] }\end{array}$ \\
\hline P83746 & TX2_THEBL & к-theraphotoxin-Tb1b & $\begin{array}{l}\text { Theraphosa blondi } \\
\text { venom }\end{array}$ & $\begin{array}{l}\text { DDCLGMFSSCDPKNDKCC } \\
\text { PNRVCRSRDQWCKYKLW }\end{array}$ & $\begin{array}{l}\text { Ebbinghaus } \\
\text { et al. [15] }\end{array}$ \\
\hline P83747 & TX3_THEBL & k-theraphotoxin-Tb1c & $\begin{array}{l}\text { Theraphosa blondi } \\
\text { venom }\end{array}$ & $\begin{array}{l}\text { DDCLGMFSSCDPNNDKCC } \\
\text { PNRVCRVRDQWCKYKLW }\end{array}$ & $\begin{array}{l}\text { Ebbinghaus } \\
\text { et al. [15] }\end{array}$ \\
\hline P82358 & GOME_ACAGO & Gomesin & $\begin{array}{l}\text { Acanthoscurria } \\
\text { gomesiana hemocytes }\end{array}$ & QCRRLCYKQRCVTYCRGR & $\begin{array}{l}\text { Silva et al. } \\
\quad[21]\end{array}$ \\
\hline Q81948 & ACN1_ACAGO & Acanthoscurrin-1 & $\begin{array}{l}\text { Acanthoscurria } \\
\text { gomesiana hemocytes }\end{array}$ & $\begin{array}{l}\text { DVYKGGGGGRYGGGRYGGGGGYGGGLG } \\
\text { GGGLGGGGLGGGKGLGGGGLGGGGLGG } \\
\text { GGLGGGGLGGGKGLGGGGLGGGGLGGG } \\
\text { GLGGGGLGGGKGLGGGGLGGGGLGGG } \\
\text { RGGGYGGGGGYGGGYGGGYGGGKYK }\end{array}$ & $\begin{array}{l}\text { Lorenzini } \\
\text { et al. [24] }\end{array}$ \\
\hline PODQJ3 & TXA1_ACAGO & $\begin{array}{l}\text { U1-theraphotoxin- } \\
\text { Agm1a }\end{array}$ & $\begin{array}{l}\text { Acanthoscurria } \\
\text { gomesiana venom }\end{array}$ & $\begin{array}{l}\text { IIECFFSCEIEKDGKSKEGKPCKPKG } \\
\text { DKDKDKKCSGGWRCKIKMCLKI }\end{array}$ & $\begin{array}{l}\text { Abreu et al. } \\
\quad[20]\end{array}$ \\
\hline PODQJ4 & GEND1_ACAGO & $\begin{array}{l}\text { U1-theraphotoxin- } \\
\qquad \text { Agm2a }\end{array}$ & $\begin{array}{l}\text { Acanthoscurria } \\
\text { gomesiana venom }\end{array}$ & $\begin{array}{l}\text { SCVHERETCSKVRGPLCC } \\
\text { RGECICPIYGDCFCYGS }\end{array}$ & $\begin{array}{l}\text { Abreu et al. } \\
\quad[20]\end{array}$ \\
\hline P0DQJ5 & VSTX1_ACAGO & $\begin{array}{l}\text { U1-theraphotoxin- } \\
\qquad \text { Agm3a }\end{array}$ & $\begin{array}{l}\text { Acanthoscurria } \\
\text { gomesiana venom }\end{array}$ & $\begin{array}{l}\text { ACGSFMWKCSERLPCC } \\
\text { QEYVCSPQWKWCQNP }\end{array}$ & $\begin{array}{l}\text { Abreu et al. } \\
\quad[20]\end{array}$ \\
\hline B3EWY4 & TXAP1_ACAPA & $\begin{array}{l}\text { U1-theraphotoxin- } \\
\qquad \text { Ap1a }\end{array}$ & $\begin{array}{l}\text { Acanthoscurria } \\
\text { paulensis venom }\end{array}$ & $\begin{array}{l}\text { IIECFFSCEIEKDGKSKEGKPCKPKG } \\
\text { DKNKDKKCSGGWRCKIKMCLKI }\end{array}$ & $\begin{array}{l}\text { Mourão et al. } \\
\qquad[31]\end{array}$ \\
\hline P0CC18 & TXL1_LASSB & $\begin{array}{l}\text { U1-theraphotoxin- } \\
\text { Lsp1a, U1-TRTX- } \\
\text { Lsp1a (LTx1) }\end{array}$ & Lasiodora sp. venom & $\begin{array}{l}\text { FFECTFECDIKKEGKPCKPKGCKCK } \\
\text { DKDNKDHKKCSGGWRCKLKLCLKF }\end{array}$ & $\begin{array}{l}\text { Vieira et al. } \\
\quad[46]\end{array}$ \\
\hline Q5Q114 & TXLT2_LASSB & $\begin{array}{l}\text { U1-theraphotoxin- } \\
\text { Lsp1b (LT×2) }\end{array}$ & Lasiodora sp. venom & $\begin{array}{l}\text { LFECTFECDIKKEGKPCKPKGCKCD } \\
\text { DKDNKDHKKCSGGWRCKLKLCLKI }\end{array}$ & $\begin{array}{l}\text { Vieira et al. } \\
\quad[46]\end{array}$ \\
\hline Q5Q113 & TXLT3_LASSB & $\begin{array}{l}\text { U1-theraphotoxin- } \\
\text { Lsp1c (LT×3) }\end{array}$ & Lasiodora sp. venom & $\begin{array}{l}\text { FFECTFECDIKKEGKPCKPKGCKCD } \\
\text { DKDNKDHKKCSGGWRCKLKLCLKF }\end{array}$ & $\begin{array}{l}\text { Vieira et al. } \\
\quad[46]\end{array}$ \\
\hline A3F7X1 & TXLT4_LASSB & $\begin{array}{l}\text { U2-theraphotoxin- } \\
\text { Lsp1a, U2-TRTX- } \\
\text { Lsp1a (LTx4) }\end{array}$ & Lasiodora sp. venom & $\begin{array}{l}\text { CGGVDAPCDKDRPDCCSYAEC } \\
\text { LRPSGYGWWHGTYYCYRKRER }\end{array}$ & $\begin{array}{c}\text { UniProtKB* } \\
\text { [47] }\end{array}$ \\
\hline A3F7X2 & TXTR3_LASSB & $\begin{array}{l}\text { U3-theraphotoxin- } \\
\text { Lsp1a, U3-TRTX- } \\
\text { Lsp1a (LT×5) }\end{array}$ & Lasiodora sp. venom & $\begin{array}{l}\text { DDSLNKGEPCQFHCECRGASV } \\
\text { LCEAVYGTRSPMYKCMIKRLPIS } \\
\text { VLDIMYQAERALEKLASSFRCE }\end{array}$ & $\begin{array}{c}\text { UniProtKB* } \\
\text { [47] }\end{array}$ \\
\hline P0CC18 & TXL1_LASPA & $\begin{array}{l}\text { U1-theraphotoxin- } \\
\text { Lp1a (LpTx1) }\end{array}$ & $\begin{array}{l}\text { Lasiodora parahybana } \\
\text { venom }\end{array}$ & $\begin{array}{l}\text { FFECTFECDIKKEGKPCKPKGCKCKD } \\
\text { KDNKDHKKCSGGWRCKLKLCLKF }\end{array}$ & $\begin{array}{l}\text { Escoubas } \\
\text { et al. [52] }\end{array}$ \\
\hline P61506 & TXL2_LASPA & $\begin{array}{l}\text { U1-theraphotoxin- } \\
\text { Lp1b (LpTx2) }\end{array}$ & $\begin{array}{c}\text { Lasiodora parahybana } \\
\text { venom }\end{array}$ & $\begin{array}{l}\text { FFECTLECDIKKEGKPCKPKGCKCN } \\
\text { DKDNKDHKKCSGGWRCKLKLCLKF }\end{array}$ & $\begin{array}{l}\text { Escoubas } \\
\text { et al. [52] }\end{array}$ \\
\hline
\end{tabular}

*Sequences registered under the title "Screening of Lasiodora sp. expression library and molecular cloning of Lasiodora sp. toxins in expression vectors" do not have any publication associated with the sequence registry. 

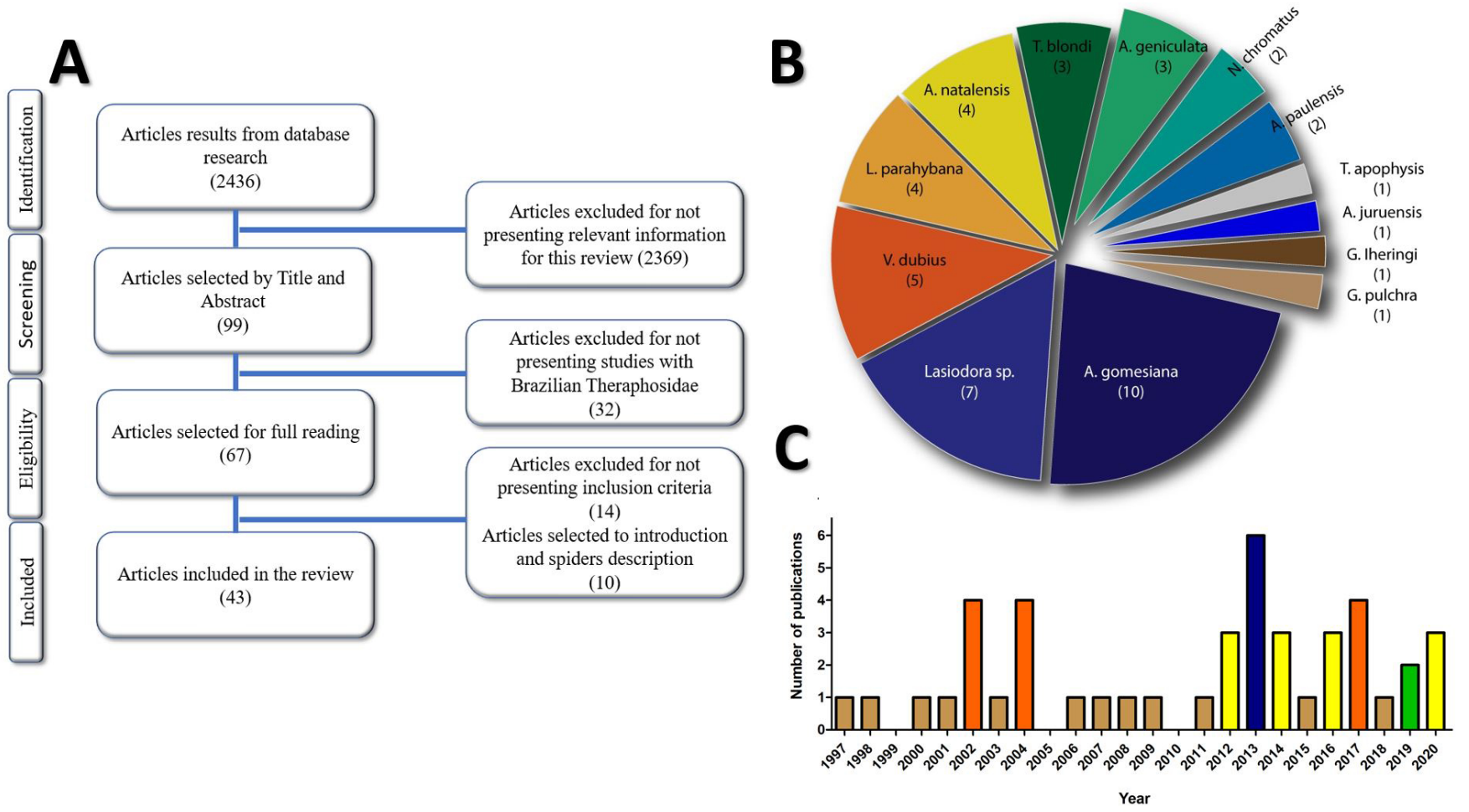

Figure 1. General results of research steps. (A) Article selection flow chart. (B) Number of articles selected for each species described. (C) Number of publications selected between 1997 and 2021.

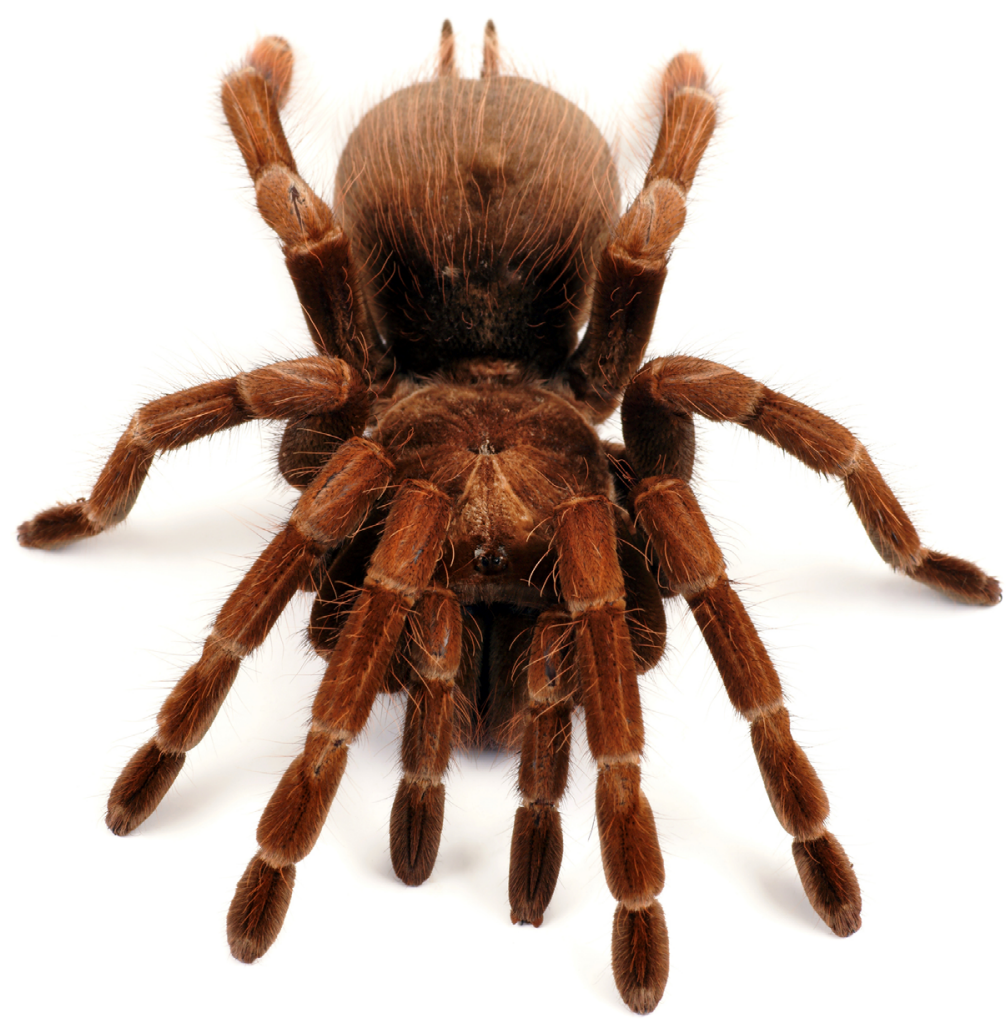

Figure 2. Specimen of Theraphosa blondi. Photo by Mirek Kijewski (ID 171295546). 
end plate potentials. The authors suggested the presence of toxins that interact with the terminal plaque receptor at the sites of acetylcholine as curare mimetic toxins, and toxins that inhibit the type $\mathrm{P}$ voltage-dependent calcium channel as an explanation for the different effects caused by the interaction of neostigmine with the venom [14].

In 2004, Ebbinghaus et al. [15] evaluated by whole-cell patchclamp the effects of $T$. blondi (referred by the authors as $T$. leblondi) venom on voltage-dependent potassium $\left(\mathrm{K}_{\mathrm{v}}\right)$ channelmediated currents. T. blondi venom inhibited A-type currents in recombinant $\mathrm{Kv} 4.2$ channels expressed by cultured hippocampal neurons from C57/Bl6 mice (Mus musculus) and HEK 293 cells, presenting selective activity in both cases. The venom was also tested on recombinant Kv1.3, Kv1.4, Kv2.1, and Kv3.4 channels also expressed in HEK 293 cells; however, the venom did not show effect against them [15].

The authors purified the venom by Reverse Phase - High Performance Liquid Chromatography (RP-HPLC) and sequenced three 35 amino acid peptides named as TLTx1, TLTx2 and TLTx 3 by tandem mass spectrometry. TLTx1 caused inhibition in recombinant $\mathrm{Kv} 4.2$ channels $\left(\mathrm{IC}_{50}=200 \mathrm{nM}\right)$, and slowed $\mathrm{Kv} 4.2$ activation kinetics. The venom also slowed the inactivation caused by macroscopic current. The authors suggested that TLTx1 may act as a Kv4.2 channel gating modifier [15].

Also in 2004, T. blondi venom was characterized through mass fingerprinting using several mass spectrometric methods, including matrix-assisted laser desorption/ionization time-offlight mass spectrometry (MALDI-TOF/MS), on-line liquid chromatography/electrospray ionization mass spectrometry (LC/ESI-MS), and nanospray ionization/hybrid quadrupole time-of-flight mass spectrometry (nanoESI-QqTOFMS). Direct nanoESI-QqTOF-MS and MS/MS experiments were considered very efficient methods for peptidomic analysis of the crude $T$. blondi venom, and the best performance was obtained using nanoESIQqTOF-MS, which detected 65 molecules with high mass accuracy [16].

Three major peptides that inhibit voltage-gated potassium channels were selected as T. blondi venom biomarkers: TlTx1, TlTx2 and TlTx3. These peptides were obtained by RP-HPLC and cleaved by trypsin, Asp-N and Glu-C endoproteinases to generate shorter fragments suitable for MS/MS experiments using a combination of nanoESI-MS/MS and MS/MS, all peptide sequences were also confirmed by Edman degradation [16].

Nowadays TlTx1, TlTx 2 and TlTx 3 are registered in Uniprot database $\kappa$-theraphotoxin-Tbla, $\kappa$-theraphotoxin-Tblb and $\kappa$-theraphotoxin-Tb1c, respectively, as seen in Table 1.

\section{Theraphosa apophysis}

T. apophysis (Tinter 1991), known as pink foot goliath tarantula, is another giant tarantula belonging to Theraphosa genus, with leg span up to $30 \mathrm{~cm}$. It occurs in Brazil, Colombia and Venezuela $[2,17]$.

Two peptides with inhibitory activity on sodium and calcium voltage-gated channels $\left(\mathrm{Na}_{\mathrm{v}}\right.$ and $\left.\mathrm{Ca}_{\mathrm{v}}\right)$ were isolated by Cardoso et al. [18] from T. apophysis venom. Both compounds present high affinity with $\mathrm{Na}_{\mathrm{v}} 1.2, \mathrm{Na}_{\mathrm{v}} 1.7$, and $\mathrm{Ca}_{\mathrm{v}} 3.1$ channels; low affinity with $\mathrm{Na}_{\mathrm{v}} 1.4, \mathrm{Na}_{\mathrm{v}} 1.5$ channels. The potency against $\mathrm{Na}_{\mathrm{v}}$ 1.6 channels was lower than observed in $\mathrm{Na}_{v} 1.7$ channels. These new peptides, named as theraphotoxin-Tapla and theraphotoxinTap2a (TRTX-Tap1a and TRTX-Tap2a) were isolated from the crude venom by RP-HPLC followed by alkylation and reduction. The molecular masses of 4179.5 (Tapla) and 3843.4 (Tap2a) Da were obtained by MALDI-TOF/MS and Edman degradation revealed sequences of 35 and 33 amino acids respectively. Recombinants of both peptides were produced by E. coli periplasmatic expression system [18].

The recombinants activities were tested by whole-cell patch clamp against the channels expressed by human HEK293 cells with rTapla showing to be more potent than rTap2a. Using male C57BL/6J mice (M. musculus) with irritable bowel syndrome a $10 \mu \mathrm{M}$ dose reduced the mechanic sensitivity of bladder, reduced nociceptive response ex vivo and visceral pain in vivo. The authors concluded that the combination of $\mathrm{Na}_{\mathrm{v}}$ and $\mathrm{Ca}_{\mathrm{v}} 3$ inhibition presents great potential in treatment of chronic visceral pain [18].

\section{Acanthoscurria gomesiana}

Acanthoscurria gomesiana (Mello-Leitão, 1923. Theraphosidae, Mygalomorphae; Fig. 3), commonly known as São Paulo Black Tarantula, has approximately $5 \mathrm{~cm}$, and is distributed in the south of Minas Gerais and northeast region of São Paulo. In nature, it can be found in natural holes, termite mounds, vicinity of roots and under rotten trunks [19].

Abreu et al. [20] investigated the complete peptidome of $A$. gomesiana venom. The peptide fraction, obtained by SolidPhase Extraction, showed antimicrobial activity against Gramnegatives E. coli SBS363 (MIC could not be obtained among the tested concentrations), E. cloacae $\beta 12$ (MIC between 22 and 45 $\mathrm{ng} / \mu \mathrm{L}$ ) and against yeast C. albicans MDM8 (MIC between 11 and $22 \mathrm{ng} / \mu \mathrm{L})[20]$.

The native peptides from the venom were analyzed by Ultra Definition Mass Spectrometry ${ }^{\mathrm{E}}\left(\mathrm{UDMS}^{\mathrm{E}}\right)$ to determine the precursor masses and allow the sequencing with the fragmented ions [20].

The peptide fraction was digested with multiple enzymes (trypsin/Lis-C, chymotrypsin, Glu-C and thermolysin) and the fragments were analyzed by LC-MS/MS. 135 peptides were found from the digestions, resulting in 17 proteins including three new theraphotoxins: (Table 1): U1-TRTX-Agm1a, which has a single aspartate (position 29) different from A. paulensis U1TRTX-Ap1; U1-TRTX-Agm2a, which derives from A. geniculata genicutoxin-D1 precursor and U1-TRTX-Agm3 [20].

Gomesin was the first antimicrobial reported from spider hemocytes. It was isolated and characterized in 2000 by Silva et al [21]. The hemolymph was centrifuged in presence of sodium citrate buffer and the hemocytes were separated, washed in the same buffer and lysed in vacuum centrifuge. The lysed hemocytes compounds were subjected to solid phase extraction, eluted in 


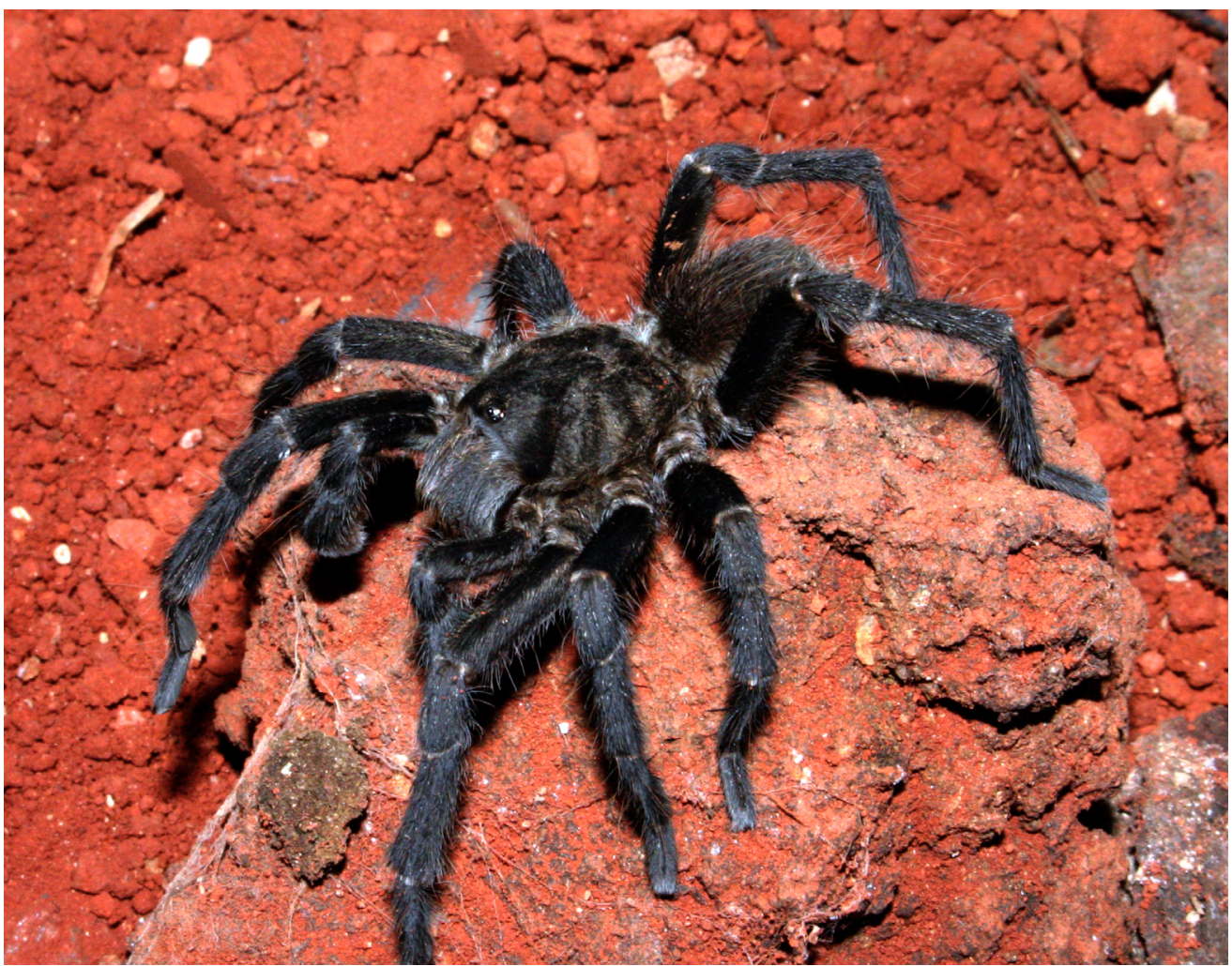

Figure 3. Male specimen of Acanthoscurria gomesiana. Collection of arachnids from the Department of Zoology, University of Brasilia, no. 3281. Photo by João de Jesus Martins.

$40 \%$ acetonitrile in acidified water, and then concentrated in vacuum centrifuge. The resultant fraction was purified by RPHPLC resulting in three antimicrobial fractions (AGH1, AGH2, and AGH3). AGH2 fraction was analyzed by MALDI-TOF/MS and ESI-MS analysis indicating a molecular mass of $2270.4 \mathrm{Da}$, and Edman degradation sequencing resulted in an 18 amino acids sequence, presented in Table 1, named as gomesin [21].

Gomesin has a pyroglutamic acid in N-terminal portion and an amidated arginine in C-terminal portion, presenting two disulfide bonds. The authors also described that gomesin has similarities with the antimicrobial peptides isolated from horseshoe crabs (Tachypleus tridentatus) tachyplesins and polyphemusins ( $50 \%$ of similarity in both cases), androctonin isolated from the Sahara scorpion (Androctonus australis) and protegrin-1, isolated from leukocytes of porcine (Sus scrofa), presented $23 \%$ and $17 \%$ of similarity, respectively. All these peptides have two disulfide bonds formed by cysteines 1-4 and 2-3 in their structures [21].

Gomesin showed activity against a wide spectrum of microorganisms including Gram-positives (MICs between 0.2 and $12.5 \mu \mathrm{M}$ ), Gram-negatives (MICs between 0.4 and 6.25 $\mu \mathrm{M}$ ), Filamentous fungi (MICs between 0.4 and $25 \mu \mathrm{M}$ ) and yeasts (MICs between 0.15 and $25 \mu \mathrm{M}$ ) as seen in Table 2. It also reduced the viability of Leishmania amazonensis promastigotes in viability assay $\left(\mathrm{IC}_{50}=2.5 \mu \mathrm{M}\right)$, as seen in Table 2 . Gomesin also showed hemolytic activity against human erythrocytes, with range between $7 \%$ and $22 \%$ in concentrations from $1 \mu \mathrm{M}$ to $100 \mu \mathrm{M}$. At low concentrations $(0.1$ and $0.2 \mu \mathrm{M})$ gomesin caused less than $5 \%$ hemolysis [21].

The three-dimensional structure of gomesin was elucidated by two-dimensional nuclear magnetic resonance (2D-NMR) followed by calculation of the molecular dynamics [22]. Gomesin exhibiting a hairpin-like structure folded in two antiparallel $\beta$-sheets (pGlu1-Tyr7 and Arg10-Arg16), with a non-canonical $\beta$-turn connecting both strands. Gomesin structure was also compared to the antimicrobials protegrin-1 (S. scrofa) and androctonin (A. australis), showing similarities in the distribution of the hydrophilic and hydrophobic residues, so it was suggested that the membrane interaction occurs in similar manner [22].

Gomesin also showed activity against melanoma cells, as described by Ikonomopoulou et al. [23]. The group compared the antiproliferative activity of gomesin (referred here as AgGom) and a gomesin-like homologous (HiGom) from the Australian spider Hadronyche infensa against murine melanoma MM96L cells with mutation in BRAF genes and normal human neonatal foreskin fibroblasts (NFF) cell line. Authors concluded that both peptides cause late apoptosis in dose-dependent manner against MM96L cells, reducing both viability and proliferation (AgGom $\mathrm{IC}_{50}=25 \mu \mathrm{g} / \mathrm{mL} ; \mathrm{HiGom} \mathrm{IC}_{50}=6.3 \mu \mathrm{g} / \mathrm{mL}$ ), but no activity against NFF cells was observed in concentrations $<50 \mu \mathrm{g} / \mathrm{mL}$. Both molecules also reduced proliferative and metastatic capacity 
Table 2. Minimal inhibition concentration of toxins extracted from Brazilian Theraphosidae spiders with confirmed antimicrobial activities.

\begin{tabular}{|c|c|c|c|c|c|c|c|c|}
\hline \multirow[b]{2}{*}{ Microorganism } & \multicolumn{8}{|c|}{ Toxin MICs } \\
\hline & Gomesin & Acanthoscurrins & $\begin{array}{l}\text { Lasiodora } \\
\text { crude venom }\end{array}$ & $\begin{array}{c}\text { Mygalin/ } \\
\text { MygAgNPs }\end{array}$ & Rondonin & Juruin & EiLAH & VdTX-1 \\
\hline Aerococcus viridans & $0.8-1.6 \mu \mathrm{M}$ & n.t & n.t & n.t & n.t & n.t & n.t & n.t \\
\hline Aeromonas sp. & n.t & n.t & $62.5 \mu \mathrm{g} / \mathrm{mL}$ & n.t & n.t & n.t & n.t & n.t \\
\hline Agrobacterium tumefaciens & n.v & n.t & n.t & n.t & n.t & n.t & n.t & n.t \\
\hline Alcaligenes faecalis & $>100 \mu \mathrm{M}$ & n.t & n.t & n.t & n.t & n.t & n.t & n.t \\
\hline Alternaria brassicola & $0.4-0.8 \mu \mathrm{M}$ & n.t & n.t & n.t & n.t & n.t & n.t & n.t \\
\hline Aspergilus fumigatus & $1.6-3.15 \mu \mathrm{M}$ & n.t & n.t & n.t & n.t & n.t & n.t & n.t \\
\hline Aspergilus niger & n.t & n.t & n.t & n.t & n.t & $5-10 \mu \mathrm{M}$ & n.t & n.v \\
\hline Bacillus cereus & $6.25-12.5 \mu \mathrm{M}$ & n.t & n.t & n.t & n.t & n.t & n.t & n.t \\
\hline Bacillus megaterium & $0.2-0.4 \mu \mathrm{M}$ & n.t & n.t & n.t & n.t & n.t & n.t & n.t \\
\hline Bacillus subtilis & n.t & n.t & $62.5 \mu \mathrm{g} / \mathrm{mL}$ & n.t & n.t & n.t & n.v & n.t \\
\hline Bacillus thuringiensis & $1.6-3.15 \mu \mathrm{M}$ & n.t & n.t & n.t & n.t & n.t & n.t & n.t \\
\hline Bauveria bassiana & $12.5-25 \mu \mathrm{M}$ & n.t & n.t & n.t & n.v & n.v & n.t & n.t \\
\hline Candida albicans IOC 45588 & $0.15-0.3 \mu \mathrm{M}$ & $1.15-2.3 \mu \mathrm{M}$ & $125 \mu \mathrm{g} / \mathrm{mL}$ & n.v & $16.5 \mu \mathrm{M}$ & $2.5-5 \mu \mathrm{M}$ & n.t & n.t \\
\hline Candida albicans MDM8 & n.t & n.t & n.t & n.v & $16.5 \mu \mathrm{M}$ & $2.5-5 \mu \mathrm{M}$ & n.t & n.t \\
\hline Candida guillermondii & n.t & n.t & n.t & n.t & $33.5 \mu \mathrm{M}$ & $2.5-5 \mu \mathrm{M}$ & n.t & $6.25-12.5 \mu M$ \\
\hline Candida glabrata & $12.5-25 \mu \mathrm{M}$ & n.t & n.t & n.t & $16.5 \mu \mathrm{M}$ & $2.5-5 \mu \mathrm{M}$ & n.t & $6.25-12.5 \mu \mathrm{M}$ \\
\hline Candida krusei & n.t & n.t & $7.8 \mu \mathrm{g} / \mathrm{mL}$ & n.t & $33.5 \mu \mathrm{M}$ & $2.5-5 \mu \mathrm{M}$ & n.t & $6.25-12.5 \mu \mathrm{M}$ \\
\hline Candida parapsilosis & n.t & n.t & $31.25 \mu \mathrm{g} / \mathrm{mL}$ & n.t & $33.5 \mu \mathrm{M}$ & $2.5-5 \mu \mathrm{M}$ & n.t & n.v \\
\hline Candida tropicalis & $3.15-6.25 \mu \mathrm{M}$ & n.t & $3.9 \mu \mathrm{g} / \mathrm{mL}$ & n.t & $16.5 \mu \mathrm{M}$ & $2.5-5 \mu \mathrm{M}$ & n.t & $6.25-12.5 \mu \mathrm{M}$ \\
\hline Cladosporium sp. & n.t & n.t & n.t & n.t & n.t & n.t & n.t & $6.25-12.5 \mu \mathrm{M}$ \\
\hline Cryptococcus neoformans & $0.8-1.6 \mu \mathrm{M}$ & n.t & n.t & n.t & n.t & n.t & n.t & n.t \\
\hline Enterobacter cloacae $\beta 12$ & $3.15-6.25 \mu \mathrm{M}$ & n.t & n.t & n.t & n.t & n.t & n.t & $50 \mu \mathrm{M}$ \\
\hline Enterococcus faecalis & $6.2-12.5 \mu \mathrm{M}$ & n.t & n.t & n.t & n.t & n.t & $227.5 \mu \mathrm{g} / \mathrm{mL}$ & n.t \\
\hline Erwinia carolovora calorovora & $3.15-6.25 \mu \mathrm{M}$ & n.t & n.t & n.t & n.t & n.t & n.t & n.t \\
\hline Escherichia coli 1106 & $0.8-1.6 \mu \mathrm{M}$ & n.t & n.t & n.t & n.t & n.t & n.t & n.t \\
\hline Escherichia coli ATCC 25922 & n.t & n.t & n.t & n.t & n.v & n.v & n.v & $6.25-12.5 \mu \mathrm{M}$ \\
\hline Escherichia coli D22 & $0.4-0.8 \mu \mathrm{M}$ & n.t & n.t & n.t & n.t & n.t & n.t & n.t \\
\hline Escherichia coli D31 & $0.8-1.6 \mu \mathrm{M}$ & $2.3-5.6 \mu \mathrm{M}$ & n.t & n.t & n.t & n.t & n.t & $6.25-12.5 \mu \mathrm{M}$ \\
\hline Escherichia coli SBS363 & $0.4-0.8 \mu \mathrm{M}$ & n.t & n.t & $85 \mu \mathrm{M} / 19-58 \mathrm{nM}$ & n.v & n.v & n.t & n.t \\
\hline Fusarium culmorum & $0.4-0.8 \mu \mathrm{M}$ & n.t & n.t & n.t & n.t & n.t & n.t & n.t \\
\hline Fusarium oxysporum & $0.4-0.8 \mu \mathrm{M}$ & n.t & n.t & n.t & n.t & n.t & n.t & n.t \\
\hline
\end{tabular}


Table 2. Cont

\begin{tabular}{|c|c|c|c|c|c|c|c|c|}
\hline \multirow[b]{2}{*}{ Microorganism } & \multicolumn{8}{|c|}{ Toxin MICs } \\
\hline & Gomesin & Acanthoscurrins & $\begin{array}{l}\text { Lasiodora } \\
\text { crude venom }\end{array}$ & $\begin{array}{l}\text { Mygalin/ } \\
\text { MygAgNPs }\end{array}$ & Rondonin & Juruin & EiLAH & VdTX-1 \\
\hline Klebsiella pneumoniae & $3.15-6.25 \mu \mathrm{M}$ & n.t & $15.62 \mu \mathrm{g} / \mathrm{mL}$ & n.t & n.t & n.t & n.v & n.t \\
\hline Leishmania amazonenses & $2.5 \mu \mathrm{M}$ & n.t & n.t & n.t & n.t & n.t & n.t & n.t \\
\hline Listeria monocytogenes & 0.8-1.6 $\mu \mathrm{M}$ & n.t & n.t & n.t & n.t & n.t & n.t & n.t \\
\hline Micrococcus luteus & $0.4-0.8 \mu \mathrm{M}$ & $>5.6 \mu \mathrm{M}$ & $7.8 \mu \mathrm{g} / \mathrm{mL}$ & n.v & n.v & n.v & n.t & $6.25-12.5 \mu \mathrm{M}$ \\
\hline Nectria haematococca & $0.2-0.4 \mu \mathrm{M}$ & n.t & n.t & n.t & n.t & n.t & n.t & n.t \\
\hline Neurospora crassa & $0.4-0.8 \mu \mathrm{M}$ & n.t & n.t & n.t & n.t & n.t & n.t & n.t \\
\hline Nocardia asteroids & $1.6-3.15 \mu \mathrm{M}$ & n.t & n.t & n.t & n.t & n.t & n.t & n.t \\
\hline Pediococcus acidolacrici & $3.15-6.25 \mu \mathrm{M}$ & n.t & n.t & n.t & n.t & n.t & n.t & n.t \\
\hline Pseudomonas aeruginosa & $1.6-3.15 \mu \mathrm{M}$ & n.t & $31.25 \mu \mathrm{g} / \mathrm{mL}$ & n.t & n.v & n.v & n.t & n.t \\
\hline Saccharomyces cerevisiae & $1.6-3.15 \mu \mathrm{M}$ & n.t & n.t & n.t & n.t & n.t & n.t & n.t \\
\hline Salmonella thyphinurium & $0.8-1.6 \mu \mathrm{M}$ & n.t & n.t & n.t & n.t & n.t & n.t & n.t \\
\hline Serralia marcescens Db11 & n.v & n.t & n.t & n.t & n.t & n.t & n.t & n.t \\
\hline Staphylococcus aureus & $1.6-3.15 \mu \mathrm{M}$ & n.t & $7.81 \mu g / m L$ & n.t & n.v & n.v & n.v & $6.25-12.5 \mu \mathrm{M}$ \\
\hline Staphylococcus epidermidis & $0.8-1.6 \mu M$ & n.t & n.t & n.t & n.v & n.v & n.t & $6.25-12.5 \mu \mathrm{M}$ \\
\hline Staphylococcus haemolyticus & $0.8-1.6 \mu \mathrm{M}$ & n.t & n.t & n.t & n.t & n.t & n.t & n.t \\
\hline Staphylococcus saprophyticus & $0.8-1.6 \mu M$ & n.t & n.t & n.t & n.t & n.t & n.t & n.t \\
\hline Streptococcus pyogenes & $1.6-3.15 \mu \mathrm{M}$ & n.t & n.t & n.t & n.t & n.t & n.t & n.t \\
\hline Tricoderma viridae & $0.4-0.8 \mu \mathrm{M}$ & n.t & n.t & n.t & n.t & n.t & n.t & n.t \\
\hline Tricophyton mentagrophytes & $0.8-1.6 \mu M$ & n.t & n.t & n.t & n.t & n.t & n.t & n.t \\
\hline Trichosporium sp. & n.t & n.t & n.t & n.t & n.t & n.t & n.t & $6.25-12.5 \mu \mathrm{M}$ \\
\hline Trichosporon sp. & n.t & n.t & n.t & n.t & $1.1 \mu \mathrm{M}$ & n.t & n.t & n.t \\
\hline $\begin{array}{l}\text { Xhantomonas campestris pv. } \\
\text { Orizae }\end{array}$ & $3.15-6.25 \mu \mathrm{M}$ & n.t & n.t & n.t & n.t & n.t & n.t & n.t \\
\hline
\end{tabular}

n.v: no value related; n.t: not tested 
in zebrafish (Danio rerio) AVATAR MM96L xenograft tumor models. AgGom and HiGom act on the cells via activation of the p53/p21 checkpoint and Hippo pathway. AgGom and HiGom also inhibit the MAP kinase pathway. The activation cascades caused by AgGom and HiGom stimulate the accumulation of reactive oxygen species (ROS), reducing the membrane potential of the mitochondria that results in the late cell apoptosis [23].

Acanthoscurrins are glycine-rich antimicrobial peptides isolated from A. gomesiana hemocytes [24]. The hemocytes were treated in the same manner described by [21] during the purification of the gomesin, and the fractions AGH1, AGH2 and AGH3 were obtained. Mass spectrometry showed that AGH2 corresponds to gomesin. This study focused on AGH3, which was purified by RP-HPLC and characterized ESI-MS/MS. Capillary electrophoresis confirmed the presence of two molecules with similar molecular masses (10,225 Da and 10,111 Da) [24].

Edman degradation and cDNA cloning confirmed two isoforms with 132 and 130 amino acids (about $73 \%$ glycine residues), named as acanthoscurrin-1 and acanthoscurrin-2 (Table 1), respectively. The only difference between both peptides is the absence of two glycine in acanthoscurrin-2. The authors described their primary structures as unique, once they did not show structural similarities with the glycine-rich antimicrobial peptides isolated from insect larvae as AFP (Sarcophaga peregrina), holotricin-3 (Holotrichia diomphalia), and tenecin-3 (Tenebrio molitor), or isolated from Brassicaceae (Capsella bursa-pastoris) as the shepherins [24].

Antimicrobial tests were performed on Microccus luteus (no activity reported using concentration up to $5.6 \mu \mathrm{M}$ ), Escherichia coli $(\mathrm{MIC}=2.3-5.6 \mu \mathrm{M})$ and Candida albicans $(\mathrm{MIC}=1.15$ $2.3 \mu \mathrm{M})$ as seen in Table 2 [24].

The third antimicrobial compound (AGH1) present in $A$. gomesiana hemocytes is an acylpolyamine, named as mygalin, characterized by Pereira et al. [25]. Authors identified mygalin between three different RP-HPLC fractions with antimicrobial activity, two of them corresponding to the previously described gomesin and acanthoscurrins. Mygalin complete purification was achieved by an additional size exclusion chromatography step. ESI-MS revealed that mygalin has $417.3 \mathrm{Da}$ [25].
The structure of mygalin (Fig. 4) was elucidated by tandem mass spectrometry (MS/MS) and two spectroscopic techniques, Nuclear Magnetic Resonance (NMR) and Ultraviolet (UV) Spectroscopy, identified mygalin as bis-acylpolyamine N1N8bis(2,5-dihydroxybenzoyl)spermidine [25].

Mygalin antimicrobial activity (Table 2) was tested against E. coli, M. luteus, and C. albicans, showing activity only against E. coli $(\mathrm{MIC}=85 \mu \mathrm{M})$. However, the activity of mygalin (2.6 to $170 \mu \mathrm{M}$ ) against $E$. coli was inhibited in catalase presence $(100 \mu \mathrm{g} / \mathrm{mL})$, so the authors concluded that antimicrobial mechanism involves the $\mathrm{H}_{2} \mathrm{O}_{2}$ production. Interestingly, the activity of mygalin against $E$. coli was 4 -fold higher (MIC = $21.2 \mu \mathrm{M}$ ) when the culture medium was supplemented with a trace elements solution. [25].

Mygalin was also described as having an immunomodulatory effect by Mafra et al. [26]. The toxicity of mygalin ( 5 to $40 \mu \mathrm{g} / \mathrm{mL}$ ) against splenocytes and macrophages collected from euthanized C57BL/6 mice was evaluated by MTT assay, which showed that mygalin did not reduce the cells viability. Mygalin activates the enzyme inducible nitric oxide synthase (iNOS) enhancing the production of nitrite and inducing the TNF- $\alpha$ production by macrophages. ${ }_{\text {L }}$-NIL, a specific iNOS inhibitor, presence ceased the nitrite production by macrophage suggesting that the nitrite production occurs independently from exogenous IFN- $\gamma$. Mygalin did not have direct action on the inflammasome complexes, once it did not induce IL- $1 \beta$ secretion or activate the caspase-1. Authors suggested that mygalin target are $T$ cells once it stimulate the production of IFN- $\gamma$, a Th1 cytokine, but does not cause the production of Th2 cytokines as IL-5 [26].

Mygalin showed anticonvulsant activity which was reported in 2013 [27], preventing seizures provoked in male Wistar rats (Rattus norvegicus) by N-methyl-D-aspartate (NMDA) and pentylenetetrazole (PTZ). Mygalin $(2 \mu \mathrm{g} / \mu \mathrm{L})$ presented anticonvulsant activity of $16.6 \%$ against seizures induced PTZ. The NMDA experiment revealed a reversed dose dependence curve, a $2 \mathrm{ng} / \mu \mathrm{L}$ dose caused reduction of $83.3 \%$ in the seizures. To evaluate possible side effects, the rats were submitted to Open field, Rotarod and Morris Water Maze tests to analysis of locomotor activity, motor impairment and neurological

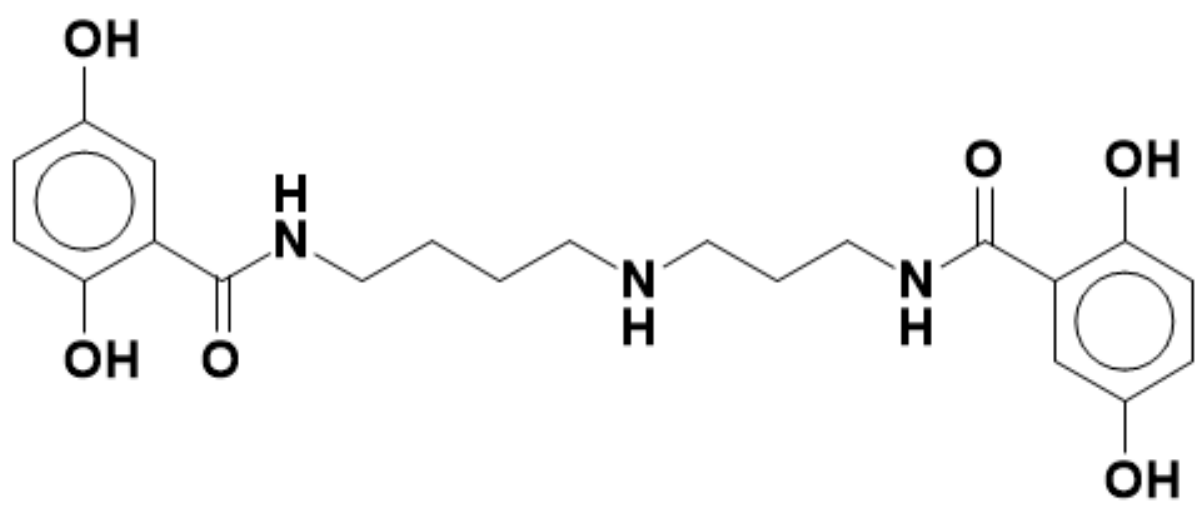

Figure 4. Mygalin structure. 
disorders. Mygalin treated rats presented mild behavioral changes in comparison to rats treated with conventional anticonvulsant drugs. Authors hypothesized that mygalin may be an antagonist to NMDA receptor [27].

Mygalin was subjected to multiple tests to elucidate the mechanisms responsible for the antimicrobial activity against E. coli. In a viability assay, mygalin $(0.5 \mathrm{mM})$ was more effective than $\mathrm{H}_{2} \mathrm{O}_{2}(1 \mathrm{mM})$ [28]. Alkaline electrophoresis gel showed that mygalin causes oxidative DNA damage, which was also observed in E. coli model by confocal microscopy. This result was supported by DNA-DAPI fluorescence assay. DAPI is a fluorescent dye that intercalates with DNA double-helix and is commonly used to evaluate structural damage on DNA. Filamentation assay with $10^{6} \mathrm{CFU} / \mathrm{mL}$ treated with $0.5 \mathrm{mM}$ for $3 \mathrm{~h}$ revealed the capacity of mygalin to interfere on cell division by binding to DNA, causing inhibition of its synthesis in vivo [28].

Mygalin (0.5 $\mathrm{mM}$ ) also showed the capacity to disrupt cells membrane, which was evaluated by propidium iodide (PI) uptake combined with esterase activity assays. The esterase was stained with CFDA and variation of membrane permeability to PI was confirmed by Confocal Microscopy. Mygalin (0.5 mM) also shows contribution to formation of ROS, which is higher than observed in the $\mathrm{H}_{2} \mathrm{O}_{2}$ controls ( $0.25,0.5$ and 1-mM doses). Authors suggested that ROS production as one of the main mechanisms behind the DNA damage [28].

Mygalin interaction with LPS was confirmed by spectrometric evaluation of free mygalin when exposed to LPS from an initial $0.5 \mathrm{mM}$ concentration. Finally, mygalin was also confirmed as a $\mathrm{Fe}^{+2}$ chelator when it in a dose-dependent manner $(0-1000$ $\mu \mathrm{M})$ reduced the dihydrorhodamine hydrochloride (DHR) oxidation [28].
Recently, the antimicrobial and antitumoral activities of seven mygalin silver nanoparticles (MygAgNPs) were evaluated by [29]. The MygAgNPs were synthetized by photoreduction method, forming spherical particles with sizes from 10 to 60 $\mathrm{nm}$ tested against $E$. coli, revealing a reasonable enhance in the antimicrobial activity (MICs between 19 and $58 \mathrm{nM}$ according to mygalin concentration used to nanoparticle synthesis) when compared to the peptide native $(\mathrm{MIC}=1 \mathrm{mM})$ form [29].

The nanoparticle named as MygAgNP1 activity was evaluated against MCF-7 cells and normal NHI/3T3 murine fibroblast (ATCC CRL-1658) in doses from 2.5 to $80 \mu \mathrm{L}$ of nanoparticles. Authors highlighted the $5 \mu \mathrm{L}$ dose, which caused death of approximately $52 \%$ of the tumoral cells, but only $13 \%$ of the NHI/3T3 cells [29].

\section{Acanthoscurria paulensis}

Distributed in all the central region of Brazil and in the states of Mato Grosso, Goiás, Minas Gerais, Mato Grosso do Sul, Paraná and Rio Grande do Sul, Acanthoscurria paulensis (Mello-Leitão, 1923; Fig. 5) is a big brownish mygalomorph, usually found inside Armitemes sp. termite mounds [30].

Mourão et al. [31] characterized the pharmacological activities of the Brazilian tarantula A. paulensis venom. A MALDI/TOF screening of 60 fractions obtained through fractionation by RP-HPLC showed a total of 97 components ranging from 600 to 22,000 Da. The molecular ions 601.4 and 728.6 Da, observed in mass spectra, were suggested as acylpolyamines corresponding to ions originally discovered in the tarantula Aphonopelma chalcodes venom and further described in Lasiodora parahybana venom [31].

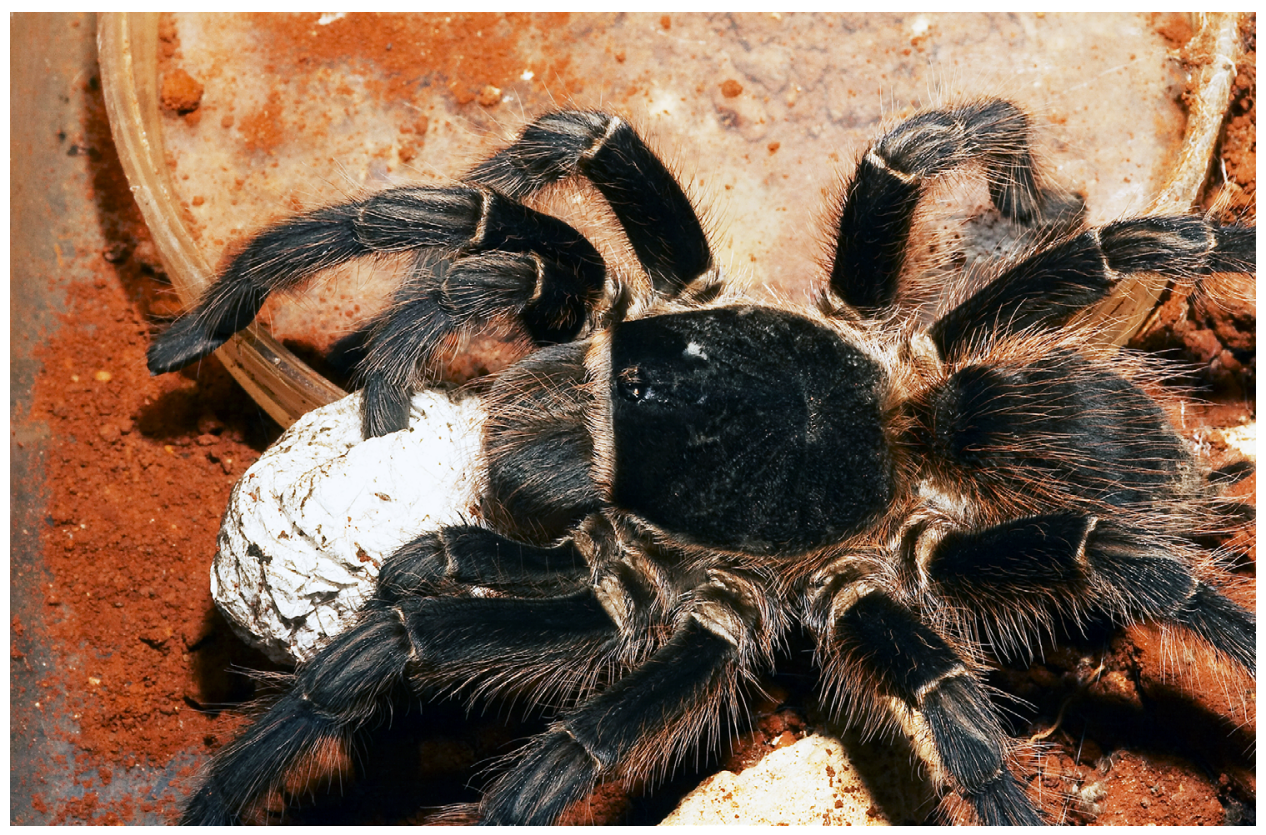

Figure 5. Female specimen of Acanthoscurria paulensis. Collection of Arachnids from the Department of Zoology, University of Brasília, no. 3423. Photo by João de Jesus Martins. 
A $20 \mu \mathrm{g} / \mathrm{g}$ A. paulensis venom dose was injected intraperitoneally in Swiss albino mice (Mus musculus), causing hypoactivity, prostration, contortion, dyspnea, ataxia and constipation. When the dose was increased to $25-30 \mu \mathrm{g} / \mathrm{g}$, abdominal spasm, anuria and general flaccid paralysis were observed, with a death rate of 60 to $80 \%$. Using $40 \mu \mathrm{g} / \mathrm{g}$ of venom, all individuals presented convulsions after cyanosis, tachycardia and spams. The $40 \mu \mathrm{g} / \mathrm{g}$ dose also resulted in death of all animals, which occurred approximately 90 minutes after the venom administration. The lethal dose for killing $50 \%$ of the mice $\left(\mathrm{LD}_{50}\right)$ was $25.4 \pm 2.4 \mu \mathrm{g} / \mathrm{g}$. Mice utilized to lethality assay were dissected, and the organs were fixed in formalin, and embedded in paraffin. Histological sections stained with hematoxylin-eosin showed no alteration in the heart, lung, kidney, liver, or spleen. The authors also attested that no nociceptive behavior was induced in concentrations up to $20 \mu \mathrm{g} /$ mice hind-paw [31].

The edematogenic activity of $A$. paulensis venom was tested with subplantar injection (20,40 and $60 \mu \mathrm{g}$ of venom/paw) in the hind paw of Wistar rats (Rattus norvegicus). The authors observed significant differences in the edema formation caused by each dose, especially when compared the lower (about $20 \%$ edema after 2 hours) and higher doses (about 50\% edema after 2 hours) [31].

Cardiotoxicity assays were performed with the frog Lithobates catesbeianus, using in situ heart and isolated ventricular slices. For this assay, it was used the crude venom $(50 \mu \mathrm{g})$, Low Molecular Mass Fraction (LMMF, $12.5 \mu \mathrm{g}$ ), and Protein Fraction (PF, 50 $\mu \mathrm{g})$. The crude venom and LMMF caused cardiac arrest, but the activity was inhibited by atropine $(2 \mu \mathrm{g})$, suggesting that the effect depends on acetylcholine receptors activation [31].

In the same year Mourão et al. [32] also identified and characterized a 48 amino acids peptide toxin from $A$. paulensis venom, named as Apla, which presents moderate similarity (67\%) with the Huwentoxin-II isolated from the spider Haplopelma schmidti. Apla was purified by RP-HPLC, exhibiting a molecular mass of $5457.79 \mathrm{Da}$ according to MALDI-TOF/MS mass spectrometry analysis. This peptide was reduced, alkylated and digested by Glu-C endopeptidase, and fragments were sequenced using Edman degradation and MS/MS, resulting in a partial sequence of 38 amino acid residues and three disulfide bonds formed by linkage of the cysteines $1-4 ; 2-5 ; 3-6$. The full peptide sequence (Table 1) was obtained by transcriptomic analysis [32].

The authors reported that Apla causes dose-dependent paralysis on Spodoptera frugiperda larvae by intraperitoneal injection $\left(\mathrm{ED}_{50}=13.01 \pm 4.21 \mu \mathrm{g} / \mathrm{g}\right)$. It also interferes on frequency and amplitude of Drosophila melanogaster Giant Fiber Tergo Trochanteral Motor neurons (GF-TTM) and Dorsal Longitudinal Motor neurons (GF-DLM), dose-dependently reducing responses to electro stimulation at $100 \mathrm{~Hz}$ in both neurons when doses between $0.21 \mathrm{pM} / \mathrm{g}$ and $4.18 \mathrm{pM} / \mathrm{g}$ were used. The responses to direct stimulation stopped after 15 minutes in all the tested concentrations [32].
Apla was applied in a single dose in Swiss albino mice ( $M$. musculus, $30 \mu \mathrm{g}$ / animal). After 10 minutes the toxin provoked urination, myoclonus and hypermobility, and animals presented generalized seizures after 12 minutes that led to death by respiratory failure 25 to 35 minutes after application [32].

Electrophysiological assays were performed using Apla at $1 \mu \mathrm{M}$, however it did not cause any stimulation in nicotine receptors expressed by rhabdomyosarcoma TE671 cells (ATCC ${ }^{\bullet}$ HTB-139). Human sodium-gated channels $\mathrm{hNa}_{\mathrm{v}} 1.2, \mathrm{hNa}_{\mathrm{v}} 1.4$, $\mathrm{hNa}_{\mathrm{v}} 1.5$ and $\mathrm{hNa}_{\mathrm{v}} 1.6$ also did not present significative effects caused by Apla [32].

\section{Acanthoscurria natalensis}

A. natalensis (Chamberlin, 1917; Fig. 6), commonly known as Natal Brown Bird eater, is a species of tarantula that occurs in the Brazilian biomes Caatinga and Cerrado. It is a non-aggressive species with wide distribution among the Brazilian States [33]. A. rondoniae (Mello-Leitão, 1923) is synonym for A. natalensis [2, 33].

Rondonin is an antifungal peptide isolated from $A$. natalensis (cited by authors as A. rondoniae) hemolymph by RP-HPLC [34]. The molecular mass of $1236.776 \mathrm{Da}$ was obtained by MALDI-TOF/MS and the 10 amino acids sequence (Table 1) was obtained by de novo analysis by liquid chromatography mass spectrometry (LC/MS) [34].

Although testes for bacteria, yeast, and fungi, rondonin only caused growth inhibition in Candida spp. (MICs between 16.5 and $33.5 \mu \mathrm{M})$ and Trichosporon sp. $(\mathrm{MIC}=2.1 \mu \mathrm{M})$ as seen in Table 2. It also did not show toxicity to human erythrocytes with $0 \%$ hemolysis in concentrations up to $134 \mu \mathrm{M}$. The results suggested that rondonin antifungal properties may be specific against yeasts [34].

Rates et al. [35] isolated, characterized primary structure and determined electrophysiological effects of the anti-insect peptide $\mu$-theraphotoxin-An1a ( $\mu$-TRTX-An1a) from the A. natalensis venom using two dimensional (cation exchange followed by RP-HPLC) or one-dimensional chromatography (RP-HPLC). A $37 \mathrm{~N}$ - terminal amino acid sequence (Table 1) was obtained by Edman degradation and complemented by tandem mass spectroscopy with LTQ Orbitrap, resulting in a 47 amino acid sequence. MALDI-TOF/MS analysis revealed that $\mu$-TRTX Anla has a molecular mass of $5370.67 \mathrm{Da}$. The sequence of $\mu$-TRTXAnla showed similarities with U1-TRTX-Hh1a, previously known as huwentoxin-II, from Haplopelma huwenum [35].

The electrophysiological experiments were conducted in cockroach (Periplaneta americana) Dorsal Unpaired Median Neurons (DUM neurons). A $100 \mathrm{nM}$ dose of $\mu$-TRTX-An1a induced membrane depolarization, increased spontaneous firing frequency and reduced the action potential amplitude peaks. The toxin produced an increase in the frequency of action potential discharge associated slight depolarization, increasing the frequency of spontaneous firing (after 15 minutes of the toxin administration), resulting in a total disappearance the potential action 20 minutes after the exposure [35]. 


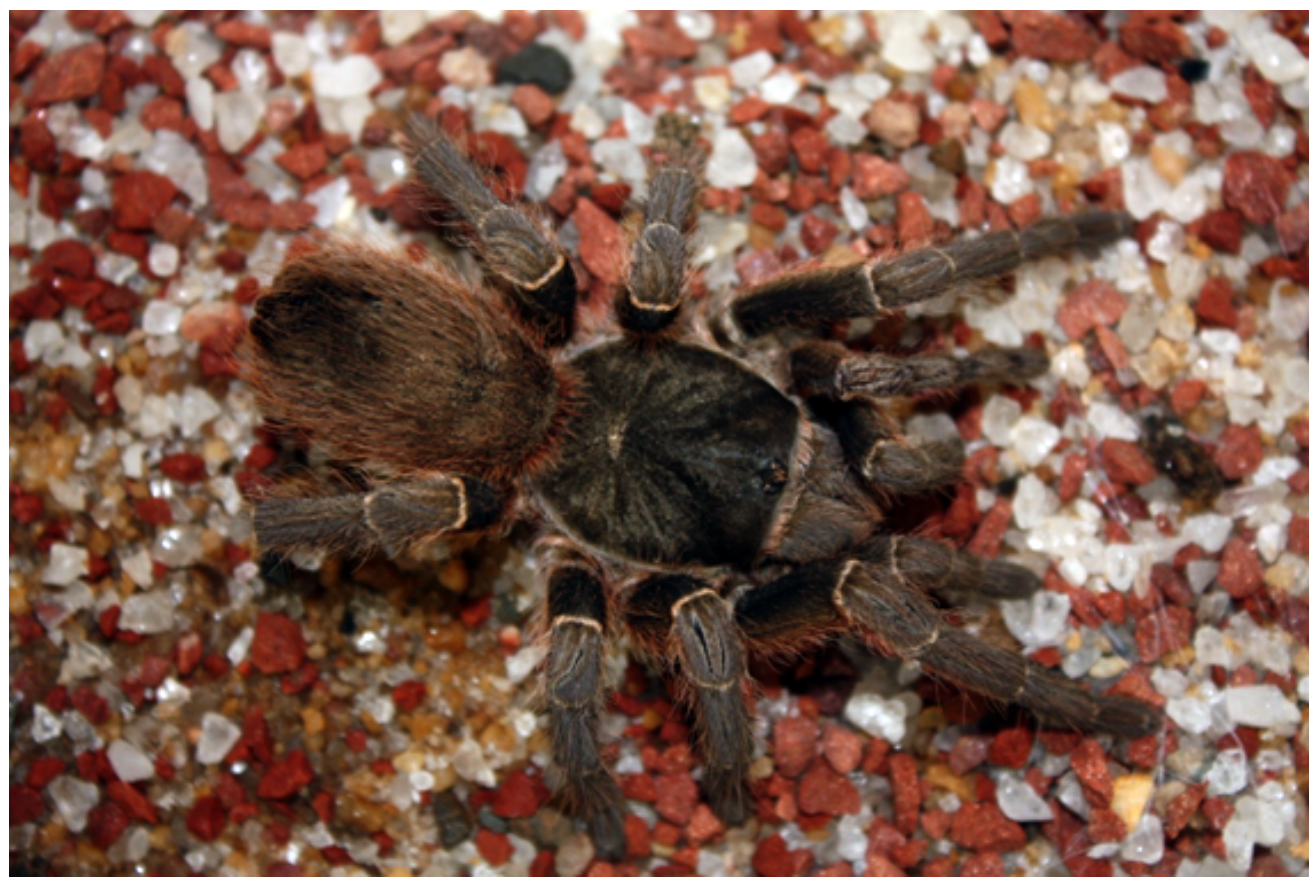

Figure 6. Acanthoscurria natalensis collected in Goiás state (Monte Alegre city). Photo by Osmindo R. Pires Jr.

The test with the whole-cell under voltage clump condition, $\mu$-TRTXAn1a $(100 \mathrm{nM})$ promoted a partial blockade of the voltage-dependent sodium current amplitude in DUM neurons, without affecting its voltage dependence [35].

Authors correlated the blockage of $\mathrm{Na}$ current with the reduction in the spontaneous action potential amplitudes. They also suggested that $\mu$-TRTX-Anla affects voltage-dependent sodium channels in insects' neurons, which are possibly one of the channels targeted by this toxin [35].

In 2019, Barth et al. [36] isolated and characterized a protein complex formed by a hyaluronidase and a cysteine-rich secretory (CRISP)-like protein from A. natalensis venom. The crude venom was purified by RP-HPLC, and a fraction with hyaluronidase activity presented $53 \mathrm{kDa}$ monomer and oligomers of 124 and $178 \mathrm{kDa}$ were obtained by 1D Blue Native PolyAcrylamide Gel Electrophoresis (BN-PAGE). A 2D BN/SDS-PAGE revealed the presence of two subunits: a portion with hyaluronidase activity and $53 \mathrm{kDa}$ named AnHyalH and a CRISP-like subunit with $44 \mathrm{kDa}$, named AnHyalC. Both subunits were sequenced by Edman degradation and compared with databases by Blast homology searches. AnHyalH showed $67 \%$ of similarity with the hyaluronidase from Brachypelma vagans, while AnHyalC presented $82 \%$ coverage with Grammostola rosea CRISP-like protein. The authors suggested that the CRISP protein present in the complex possibly contributes with AnHyal enzymatic activity [36].

In 2020, a multiomic study (venom gland transcriptomic, venom proteomic and peptidomic) was performed with $A$. natalensis (referred by authors as $A$. rondoniae) to present this approach as a viable method to identify and characterize peptides while investigating antimicrobial, antiviral and antitumoral activities in silico [37]. The venom glands were extracted, and the cDNA library obtained by TruSeq RNA Sample Prep Kit protocol followed by de novo assembly to eliminate redundancies, resulting in 92,889 transcripts [37].

To perform the proteomic and peptidomic analysis both the crude venom and aliquots digested with trypsin (for both analysis), Asp-N, Glu-C, chymotrypsin and thermolysin (only for peptidomic) were reduced and alkylated prior to analysis by nano flow LC-MS/MS. The combination of both techniques resulted in 18 toxins fully sequenced, quantified and validated: 11 Cysteine Rich Proteins, with one characterized as the U1TRTX-Agm3a isolated from A. gomesiana venom and 10 new CRPs; and 7 peptides shorter than 10 amino acids [37].

The in silico predictions were realized with the CRPs revealing high antibacterial (scores from 0.843 to 0.997 ), antifungal (0.579 - 0.989) and antiviral $(0.696-0.968)$ potentials with the U1TRTX-Agm3a and a CRP named as U1-TRTX-Arlb also revealing antitumoral potential tested by Random Forest and Support Vector Machine Anticancer Peptide Methods. The short peptides present lower antimicrobial and antiviral potentials than the CRPs, however 4 of them (sequences: PLPVFV, VPPILKY, VVVPFVV and VLPPLKF) present scores above 0.5 in both methods and have been characterized as potential anticancer peptides [37].

\section{Acanthoscurria geniculata}

A. geniculata (Koch, 1941), commonly known as Brazilian Whiteknee Tarantula. Found in the Brazilian states of Rondônia, Roraima, Pará, and Mato Grosso, and identified by its coloration pattern with pink setae on legs and at the front border of the carapace $[2,38]$. 
Sanggaard et al. [39] realized a genomic study with $A$. geniculata (Mygalomorph model) and Stedodyphus mimosarum (Araneomorph model) to determine the influence of predation methods in the composition of venom, silk and digestive fluids produced by these species [39].

For the venom characterization of A. geniculata, the crude venom was analyzed by SDS-PAGE revealing two main bands, the first with $45 \mathrm{kDa}$ and a second with proteins below $10 \mathrm{kDa}$. Both bands were digested in gel with trypsin to analysis by LCMS/MS followed by the quantification of the proteins obtained by spectral counting realized by extracted-ion chromatography. The quantification revealed that the most part of these proteins' present homology with CRISP3, but were also found two metaloendoproteinases, a pancreatic-like triacylglycerol lipase, a carbonic anhydrase, and a hyaluronidase. Authors suggested that the venom proteases major role is the activation of protoxins once them present homology with the proteases that cause activation precursor proteins [39].

In a study realized in 2017, Walter et al. [40] investigated the correlation between the venom injection and extra-oral digestion using A. geniculata model of Theraphosidae. For this purpose, the authors realized an overlap of the venom and digestive fluids proteins, to determine a possible role of the venom in the extra-oral digestion. The digestive fluids were extracted and analyzed by nano flow LC/MS-MS and 36 from 294 proteins were quantified. The overlap with the venom toxins previously described by [39] showed the presence of 11 common proteins from 118 present in the composition of the venom [40].

Wilson et al. [41] isolated and characterized two novel polyamines from the venom of multiple Theraphosidae spiders, including A. geniculata. Thirty-one species of the Theraphosidae family were selected to an initial cytotoxic evaluation of the crude venom against MCF-7 cells, and 17 of them presented significant activity (considered by authors as over $50 \%$ inhibition when compared with the control). From those, 8 venoms were chosen to be fractionated by RP-HPLC, including the one from A. geniculata and the resultant fractions were submitted to cytotoxic assays against MCF-7, SK-MEL-28 (ATCC ${ }^{\circ} \mathrm{HTB}-72$ ) and NFF cells [41].

All the venoms presented early eluting fractions with activity against MCF-7 cells. The polyamine $\mathrm{PA}_{366}$ was isolated from Phlogius sp. venom by RP-HPLC. The venoms from the other seven spiders were analyzed by one-dimensional NMR spectroscopy, which confirmed the presence of the molecular mass $366.2573 \mathrm{Da}$, corresponding to $\mathrm{PA}_{366}$ in the venom of $A$. geniculata [41].

The $\mathrm{PA}_{366}$ presents an aromatic head group (2-hydroxy-3-(4hydroxyphenyl)propanal) which is possible correlated with the cytotoxicity showed by the molecule, once this group is the only structural difference between $\mathrm{PA}_{366}$ and another polyamine named as $\mathrm{PA}_{389}$, which only displayed cytotoxic activity in concentration higher than $1 \mathrm{mM}$, while $\mathrm{PA}_{366}$ is active even in concentrations varying from 1 to $10 \mu \mathrm{M}$. Authors suggested that $\mathrm{PA}_{366}$ may cause paralysis in preys due the similarities with $\mathrm{PA}_{389}$. [41].

\section{Avicularia juruensis}

Avicularia juruensis (Mello-Leitão 1923; sub-family Aviculariinae), mostly found in Amazonia, is commonly known as Amazonian pink toe spider. They occur in South America (Brazil, Ecuador, Peru, and Colombia) and can be found in tree trunks between 1.5 and $3 \mathrm{~m}$ high. Most inhabited trees accommodated single individuals [42, 43].

Ayroza et al. [42] fractioned A. juruensis crude venom by RPHPLC, fractioned A. juruensis crude venom, and the obtained fractions were used to determine antimicrobial activity by liquid growth inhibition assays for target pathogens. The antimicrobial assay showed the presence of four antimicrobial fractions, which were purified by 11 compounds ranging molecular weight from 3.5 to $4.5 \mathrm{kDa}$ [42].

Juruin is an alternative name to U-theraphotoxin Ajula, the first Juruen toxin to be completely purified, MALDI-TOF/MS analysis revealed a 4005.83 Da molecular mass and the sequence of 38 amino acids (Table 1) was obtained by de novo sequencing. Juruin exhibits three disulfide bonds, between the cysteines 1-4, $2-5$ and 3-6, the same array is common to all the toxins from spiders that contain ICK motif [42].

Juruin showed antifungal activity against Candida spp. (MICs between 2.5 and $5 \mu \mathrm{M}$ ), and Aspergilus niger (MIC between 5 and $10 \mu \mathrm{M}$ ). However, it did not show activity against $M$. luteus, S. epidermidis, S. aureus, E. coli, P. aeruginosa, and B. bassiana even at $100 \mu \mathrm{M}$. Juruin did not exhibit hemolysis against human erythrocytes in concentrations up to $10 \mu \mathrm{M}$ [42].

\section{Lasiodora sp.}

The genus Lasiodora (Koch 1850) are referred as tarantula birdeating spiders or baboon spiders. The 33 known species are distributed among Brazil, Argentina, Uruguay, Bolivia and Costa Rica, with 25 of them occurring only in Brazil [2]. It is generally considered hazardous due to its size and appearance (Fig. 7), but there are no reports of human deaths caused by these species [3].

In 2001, Kushmerick et al. [44] evaluated the activity of the venom against murine $\mathrm{GH} 3$ cells (ATCC ${ }^{\oplus} \mathrm{CCL}-82.1$ ) $\mathrm{Ca}^{2+}$ and $\mathrm{Na}^{+}$channels by whole-cell patch clamp and imaging analysis. The crude and dialyzed venom $(400 \mu \mathrm{g} / \mathrm{mL})$ made the normal oscillations of $\mathrm{Ca}^{2+}$ in $\mathrm{GH} 3$ cells stop and affected the L-type $\mathrm{Ca}^{2+}$ channel by reducing the channel conductance and the intracellular $\mathrm{Ca}^{2+}$ in the presence of $\mathrm{Na}^{+}$channels blocked by tetrodotoxin (TTX). The activity does not change in presence of muscarinic receptors blocked by atropine. At last, the experiment was conducted without TTX, however, the venom still affected the $\mathrm{Ca}^{2+}$ oscillations, suggesting that the venom also acts in the $\mathrm{Na}^{+}$channels [44].

Kalapothakis et al. [45] tested the Lasiodora venom in the isolated heart of male Wistar rats ( $R$. norvegicus). When administered in concentrations varying from 10 to $100 \mu \mathrm{g}$, the venom caused a reversible dose dependence response, decreasing the heart rate. The highest dose provoked bradycardia and transient cardiac arrest. The venom effect was potentiated 


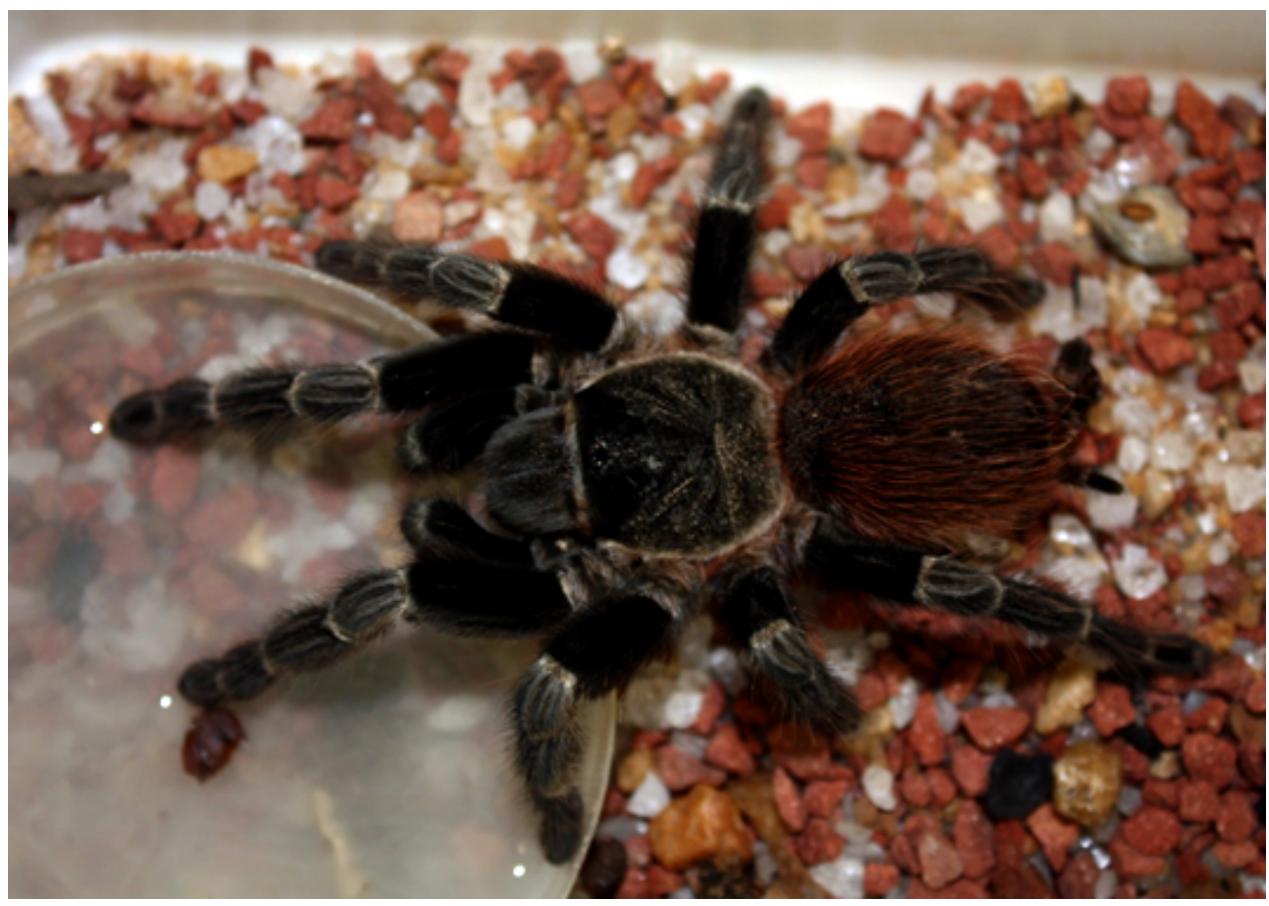

Figure 7. Lasiodora sp. collected in Bahia state (Correntina city). Photo by Osmindo R. Pires Jr.

when applied in presence of anticholinesterase, neostigmine or tetrodotoxin; however, vesamicol (drug that act pre synaptically by inhibiting acetylcholine), reduced the effects and atropine completely blocked the venom effects. The authors concluded that the venom activates TTX-resistant $\mathrm{Na}^{+}$channels causing the release of acetylcholine vesicles from parasympathetic terminals [45].

In 2004, Vieira et al. [46] described LTx1, LTx2, and LTx3 (Table 1) from a Lasiodora sp. venom gland cDNA library. The cDNA library screening was realized with ELISA, wholevenom antisera and PCR techniques. The three lasiotoxins showed significant levels of similarity with HwTX-II from Selenocosmia huwena, BsTX from Brachypelma smithii and ESTX from Eurypelma californium, toxins already described from Theraphosidae spiders [34]. LTx1, LTx2, and LTx3 were further named to U1-theraphotoxin-Lspla, U1-theraphotoxinLsp1b, U1-theraphotoxin-Lsplc, respectively (Table 1) [46].

Another two predicted sequences of toxins presented in Lasiodora sp. venom were registered in UniProt Database. Originally known as LTx4 and LTx 5 , these toxins are now entitled U2-theraphotoxin-Lspla and U3-theraphotoxin-Lspla (Table 1), under the entries A3F7X1 and A3F7X2 [47].

Dutra et al. [48] expressed and pharmacologically characterized LTx2. This toxin was expressed by transformed E. coli BL21DE3 and purified by RP-HPLC. Imaging analysis on confocal microscopy was performed to evaluate the LTx2 recombinant activity on $\mathrm{Ca}^{2+}$ channels of murine $\mathrm{BC} 3 \mathrm{H} 1$ cells (ATCC ${ }^{\circ} \mathrm{CRL}-1443$ ) revealing the toxin capacity to completely block L-type $\mathrm{Ca}^{2+}$ channels at $80 \mu \mathrm{M}$ even without the presence of TTX, which provoked the same effect at $1 \mu \mathrm{M}$ [48].
Soares et al. [49] reported in 2011, the purification and characterization of the first serine protease inhibitor extracted from Lasiodora sp. hemocytes, which was named EILaH. The hemocyte extract shows activity against trypsin, chymotrypsin, urokinase, tissue plasminogen activator, and human neutrophil elastase, with the last subtract getting 99\% of inhibition. EILaH was purified by affinity chromatography (Trypsin-Sepharose column) followed by RP-HPLC, and then analyzed by SDSPAGE, revealing an $8 \mathrm{kDa}$ protein. MALDI-TOF/MS analysis confirmed the presence of an 8274 Da protein, which was partially sequenced by Edman degradation resulting in the $\mathrm{N}$-terminal sequence LPC(PF)PYQQELTC [48]. The authors also evaluated the antimicrobial activity of both EILaH and Lasiodora sp. hemocyte extract against B. subtilis (ATCC-6633), S. aureus (ATCC-6538), E. faecalis (ATCC-6057), E. coli (ATCC-25922) and K. pneumoniae (ATCC-29665) as seen in Table 2. EILaH only showed activity against $E$. faecalis (MIC $=227.5 \mu \mathrm{g} / \mathrm{mL}$ ), while the hemocyte extract presented activity against $B$. subtilis and E. faecalis (MICs were not present by authors), indicating the presence of other antimicrobial agents in the hemocytes [49].

Horta et al. [4] demonstrated that Lasiodora sp. venom caused dose-dependent vasodilatation in male Wistar rats $(R$. norvegicus) aortic rings contracted with phenylephrine $\left(\mathrm{IC}_{50}=\right.$ $6.6 \pm 1.8 \mu \mathrm{g} / \mathrm{mL}$ ), but only when in contact with a functional endothelium. The venom also caused the Ser ${ }^{177}$ phosphorylation activating endothelial nitric oxide synthase (NOS) function, which was determined by Western Blot. The active compound present in the venom was isolated using RP-HPLC, analyzed in ESI-MS/MS, which revealed two ions with 348.1 and $136.2 \mathrm{Da}$, and through NMR it was possible to confirm that these ions 
correspond to diphosphate adenosine (ADP) and adenosine monophosphate (AMP). The authors suggested that ADP is the main component for the vasodilatation effect caused by the Lasiodora sp. venom [4].

The description of antimicrobial activity of Lasiodora sp. crude venom, was realized in 2016 using concentrations ranging from 3.9 to $500 \mathrm{mg} / \mathrm{mL}$ [50]. It was observed that the venom is bacteriostatic (more than $50 \%$ of inhibition when compared to the control) for S. aureus, P. aeruginosa, and K. pneumoniae; bactericidal (more than $90 \%$ of inhibition when compared with the control) to Aeromonas sp., B. subtilis, and M. luteus; fungistatic against $C$. tropicalis and C. cruzei and fungicidal against $C$. parapsilosis and $C$. albicans. The activity against human peripheral blood mononuclear cells (PBMC) was also evaluated, which resulted in an induction of apoptosis at 0.1 $\mathrm{mg} / \mathrm{mL}$ of crude venom, showing that the venom is cytotoxic. However, when tested against $M$. musculus erythrocytes, it demonstrated low hemolytic activity $\left(\mathrm{EC}_{50}=757 \mathrm{mg} / \mathrm{mL}\right)$ [50].

The authors also fractionated the crude venom by RP-HPLC, and fractions were submitted to electrospray tandem mass spectrometry with a quadrupole/orthogonal acceleration timeof-flight spectrometer (Q-TOF/MS). They presented homology with the peptides U1-theraphotoxin-Lpla (lasiotoxin-1), U1theraphotoxin-Lp1c (lasiotoxin-3), U3-theraphotoxin-Lspla (LTx5), and U-theraphotoxin-Asp3a. The mass spectrometry also identified proteins as Phospholipase A2 (PLA $)$ and Hyaluronidase [50].

\section{Lasiodora parahybana}

Lasiodora parahybana (Mello-Leitão, 1917; Fig. 8) is commonly known as Salmon pink tarantula [51]. This species is endemic to Brazil, occurring in North Eastern region of the country $[2,51]$.

Escoubas et al. [52] described two neurotoxins isolated from L. parahybana venom, LpTx1 and LpTx2, purified in two chromatography steps (ion exchange HPLC followed by RP-HPLC). The crude venom toxicity was tested intracerebroventricularly in mice (M. musculus) and intrathoracically in crickets (Gryllus bimaculatus). Both species presented paralysis followed by death. However, the mice's first presented symptoms were an increase in motor activity and restlessness with death occurring 40 minutes after the injection. In crickets, both paralysis and death occurred quickly after injection. The fractions with activity were isolated, submitted to reduction, alkylation, and sequenced by Edman degradation. LpTx1 and LpTx2 have 49 amino acids sequences (Table 1) with only two different amino acids. MALDI-TOF/ MS analysis revealed molecular masses of 5722 and $5674 \mathrm{Da}$, respectively. The toxins present high homology (74\%) with toxins isolated from the spiders Eurypelma californicum (ESTX) and Brachypelma smithii (BSTX). To the publication date, molecular targets are still unknown [52].

Currently, the toxins LpTx1 and LpTx2 are registered in Uniprot database as U1-theraphotoxin-Lpla and U1-theraphotoxin-Lplb, respectively (Table 1 ).

In 2002, Escoubas et al. [53] studied sex-linked variations on the venoms of eight species of spiders, including L. parahybana,

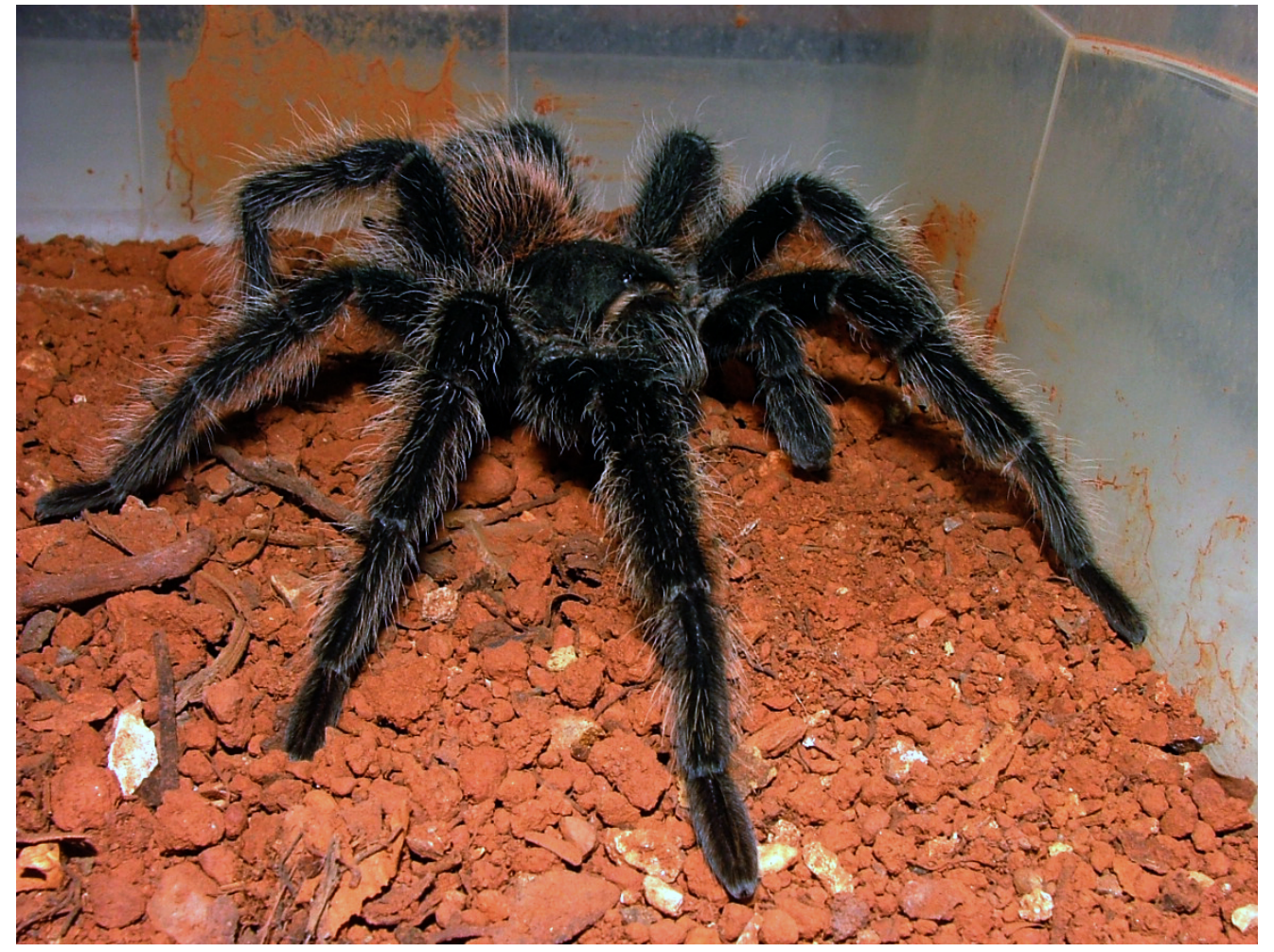

Figure 8. Male specimen of Lasiodora parahybana. Collection of Arachnids from the Department of Zoology, University of Brasília, no. 3681. Photo by João de Jesus Martins. 
and demonstrated by RP-HPLC that there is no expressive qualitative variation. However, in MALDI-TOF/MS analysis authors identified molecular masses 3106.6 Da and 3535.3 Da present only in female individuals, and molecular masses 3918.1, 7841.9, and 8274.3 Da only in male individuals, showing that quantitative difference exists between sexes, but they concluded that the venom does not show representative variation when compared the sex of L. parahybana [53].

Escoubas and Rash [1] made a general comparison of many tarantula venoms. The lasiotoxins presented in L. parahybana (LpTx1 and LpTx2, also known as U1-theraphotoxin-Lspla and U1-theraphotoxin-Lsplb, as seen in Table 1) venom have larger sequences ( 49 amino acids, Table 1) than the average 31-41 amino acid of the peptides extracted from Tarantula's venom. Lasiotoxins were classified as DDH (disulfide directed $\beta$-hairpin) and their primary sequences compared with Eurypelma spider toxins (ESTxs) and Huwentoxin-II from Selenocosmia huwena (HwTxII), indicating that they assume the same conformation even with the extra 13 amino acids, forming a fourth disulfide bond [1].

The peptide profile of $L$. parahybana venom gland using conventional methods such liquid chromatography coupled to an electrospray-ionisation hybrid quadrupole time of flight mass spectrometer (LC/ESI-QqTOFMS), matrix-assisted laser desorption/ionization time-of-flight (MALDI-TOF/MS) [53]. The analysis of fresh tissue was performed by MALDI-TOF/ MS along with venom direct analysis by nanoESI-QqTOF/MS. These experiments resulted in 81 monoisotopic molecular masses ranging from 601.38 to $43499 \mathrm{Da}$ with the molecules 601.38, 729.35, 3846.17, 424.60, 4691.03, 4846.36, 5020.39, and 7759.73 Da been considered representative of the mass fingerprint once they are always presented in the spectra [54].

The authors also compared the venom of juvenile L. parahybana (4-years old) and adults (8 and 14 years old). The major difference presented by juvenile to 8 years adult spiders was the presence of a $5723.76 \mathrm{Da}$ ion and absence of a 5642.48 ion. The 14 years adults presented the same molecular masses of the 8 years old but fractions with more intensity. The in situ analysis showed differences on the peptide levels in different cells distributed in the gland, suggesting that the compounds are produced by different cell subpopulations. One of these different compounds is an $8668.94 \mathrm{Da}$ molecule found on the top of the gland that was supposed to be a novel non-processed precursor or an enzyme involved in the toxin maturation [54].

\section{Grammostola iheringi}

Grammostola iheringi (Keyserling, 1891) is a Theraphosidae South American spider. Found in Southern states of Brazil, Northern states of Argentina, Chile, Paraguay, and Uruguay [55].

G. iheringi venom was studied using a proteomic a bottom-up approach multidimensional protein identification technology (MudPIT) approach [56]. PepExplorer tool was used for bioinformatics analysis comparing proteins based on phylogenetically close organisms, resulting in 395 proteins identified from the venomous extract. Approximately $70 \%$ of these proteins were classified as predicted, matching with neurotoxins that act on ion channels, proteases such as serine proteases, cysteine proteinases, metalloproteinases, aspartic proteinases, carboxypeptidases and cysteine-rich secretory enzymes (CRISP), and molecules with unknown targets. The other 30\% matched with proteins and enzymes already described in databases. De novo sequences showed high similarity with sequences from spiders and scorpions [56].

\section{Grammostola pulchra}

Grammostola pulchra (Mello-Leitão, 1921), is a species of spider endemic to Brazil known as Brazilian black tarantula, occurring in the states of São Paulo, Paraná, Santa Catarina and Rio Grande do Sul $[2,57]$

In 1998, Escoubas et al. [58] described a combination of RPHPLC, capillary electrophoresis and MALDI-TOF/MS in order to create a venom fingerprint of its peptides as an effective method to solve problems as identification of samples (animal or venom source) or evaluation of similarity of spiders based in the venom. Among the animals used to develop this study were two samples of Grammostola, one previously identified as G. pulchra and a Grammostola sp. specimen. MALDI-TOF/MS of both samples presents 25 molecular masses ranging from 3410 to $6855 \mathrm{Da}$ with minor changes of intensity and mass between each other. With the combination of data obtained from the chromatography, mass spectrometry and CZE electrophorograms the authors concluded that both specimens are G. pulchra [58].

\section{Vitalius dubius}

Vitalius dubius (Mello-Leitão, 1923) is a medium-sized, nonaggressive Theraphosidae found in southeastern Brazil, occurring in the southern part of the Brazilian state of Minas Gerais and in the state of São Paulo [59].

A partial characterization of $V$. dubius venom was performed in 2009 [60]. The venom presented hyaluronidase activity in turbidimetric assay and confirmed by hyaluronic acid SDS-PAGE zymogram. Aliquots up to $300 \mu \mathrm{g}$ of venom did not show any proteolytic activity against elastase, casein, and collagen [60]. An ELISA test was performed using $0.3 \mathrm{mg} / \mathrm{mL}$ of $V$. dubius venom against an IgG purified by affinity from arachnidic antivenom produced from Phoneutria nigriventer, Loxosceles gaucho, and Tityus serrulatus. V. dubius venom presented lower cross-reactivity when compared with $0.1 \mathrm{mg} / \mathrm{mL}$ of $P$. nigriventer and T. serrulatus venoms. SDS-PAGE electrophoresis (15\%) showed molecular masses varying from 6 to $130 \mathrm{kDa}$, followed by immunoblotting in polyacrylamide gels $(10 \%)$ showing molecular masses with at least $30 \mathrm{kDa}$. The venom was also purified by RP-HPLC resulting 13 fractions (described as 5 major and 8 minor fractions) [60].

In 2014, Sutti et al. [61] described a hyaluronidase (hyase) purification from the venom using gel filtration and RP-HPLC. 
The hyaluronidase had $43 \mathrm{kDa}$ mass, obtained by SDS-PAGE analysis. The activity is specific to hyaluronic acid and the optimal conditions for activity were $\mathrm{pH}$ between 4 and 5; temperature between 35 and $40^{\circ} \mathrm{C}$. The addiction of chondroitin decreased the activity, however, antilonomic, antiophidic, and antiscorpionic serum to hyase did not inhibit its enzymatic activity. However, hyase activity was inhibited by antiaracnidic serum in a dosedependent manner [61].

A toxin of 728 Da named VdTX-1 was purified by Rocha-eSilva et al. [62] from the venom of $V$. dubius. VdTX-1 showed a neuromuscular activity capable of blocking nicotinic receptor. The toxin was tested in biventer cervicis muscles of male Swiss white mice and male HY-LINE W36 chicks. Authors suggested that $V$. dubius venom contains at least two components that affect neurotransmission in vertebrates. The venom caused progressive neuromuscular blockade, which was reversible by washing, and muscle contracture. Contractures caused by the application of acetylcholine and $\mathrm{KCl}$ were attenuated by the venom. VdTX-1 also abolished carbachol-induced depolarizations and blocked nicotinic receptors non-competitively to produce reversible blockade without muscle contracture [62].

VdTX-1 has antimicrobial activity described by Sutti et al. [63]. The toxin presented activity against multiple fungi and bacteria (Table 1), among Candida species, Gram-positive bacteria and two strains of E. coli with MICs ranging from 6.25 to $50 \mu \mathrm{M}$ [63].

Rocha-e-Silva et al. [64] described the formation of edemas in male Wistar-Hanover rats ( $R$. norvegicus) caused by $V$. dubius crude venom. The venom was applied in dorsal skin or hind paw of the rats provoking dose dependent response, which was measured by plasma extravasation [64].
To elucidate the mechanisms behind this activity, the authors evaluated the plasma extravasation caused by the venom in presence of a pool of receptor antagonists to the potential pathways involved in the formation of edemas: cyproheptadine ( $2 \mathrm{mg} / \mathrm{kg}$ ), for both serotonin 5-hydroxytryptamine ${ }_{1 / 2}$ and histamine $\mathrm{H}_{1}$ receptors completely inhibited of the plasma extravasation; indomethacin (10 mg/kg), a nonselective COX inhibitor, the nitric oxide synthase inhibitor L-NAME (100 $\mathrm{nm} /$ site) and neurokinin $\mathrm{NK}_{1}$ receptors antagonists known as SR140333 (1 nm/site) caused partial abolition of the plasma extravasation; bradykinin $\mathrm{B}_{2}$ receptor JE049 (0.6 mg/kg), mepyramine (histamine $\mathrm{H}_{1}$ receptor inhibitor, $6 \mathrm{mg} / \mathrm{kg}$ ), and SR48968 (neurokinin $\mathrm{NK}_{2}$ receptor inhibitor $0.3 \mathrm{~nm} / \mathrm{kg}$ ) did not caused any reduction of the plasma extravasation [64].

With these results, the authors suggested that the edema formation caused $V$. dubius venom involves serotonin, COX products and nitric oxide, but does not involve histamine and bradykinin. The neurokinins results indicate the participation of tachykinin mediated by $\mathrm{NK}_{1}$ neurokinin receptors [64].

\section{Nhandu chromatus}

Nhandu chromatus (Schmidt, 2004; Fig. 9) is a Brazilian endemic spider commonly known as red and white tarantula. It is a terrestrial species, usually found in burrows and presents approximately $17 \mathrm{~cm}$ of leg spam $[2,65]$.

Rodríguez-Rios et al. [66] described hyaluronidase as a common component of Theraphosidae venom. In 2017, the authors conducted an experimental investigation in the venom of 13 different species including $N$. chromatus, with all presenting hyaluronidase activity in bands varying from 34 to $46 \mathrm{kDa}$ [66].

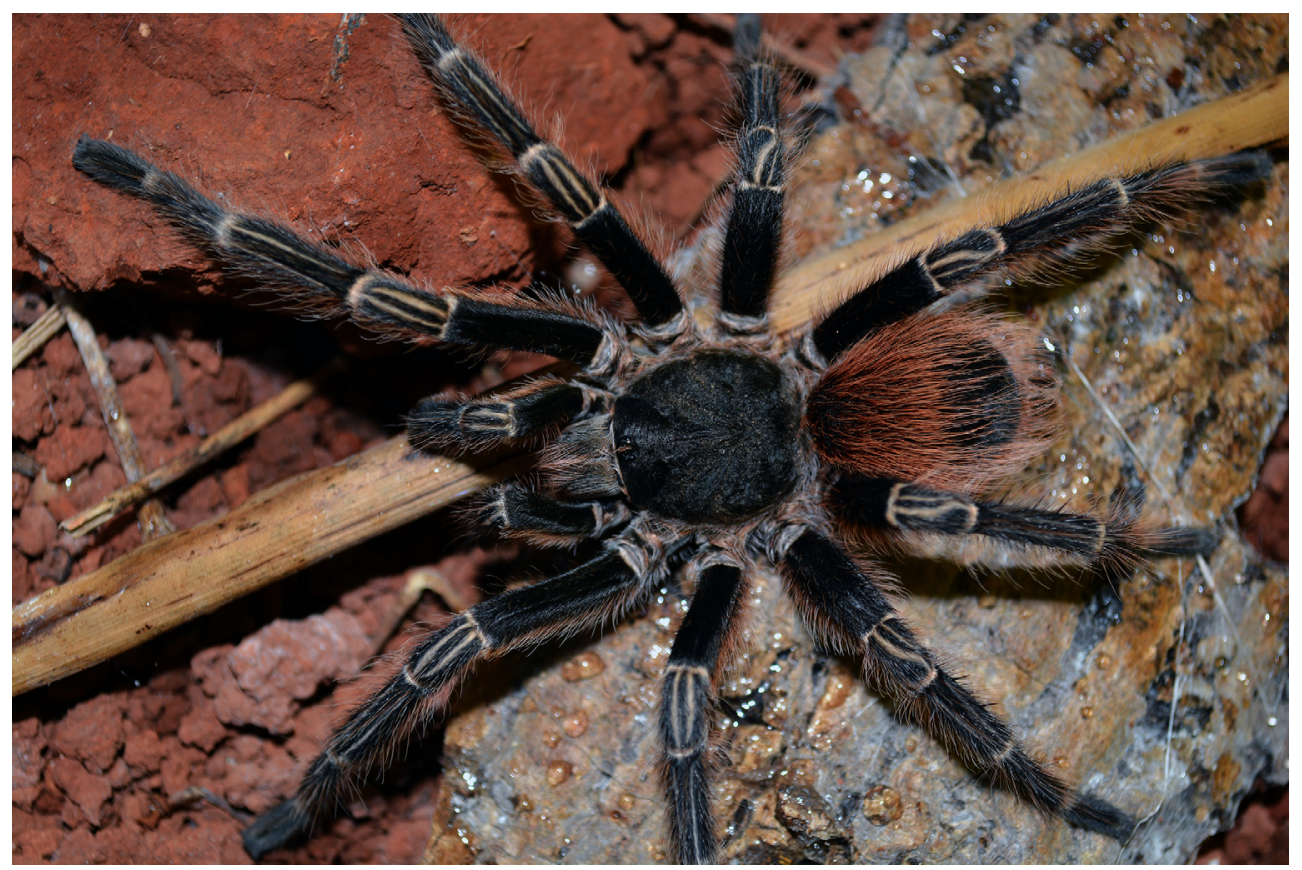

Figure 9. Male specimen of Nhandu chromatus. Collection of Arachnids from the Department of Zoology, University of Brasília, no. 8716. Photo by Paulo César Motta. 
$N$. chromatus venom was analyzed by tricine-SDS-PAGE followed by a 2D-SDS-PAGE, the low molecular mass compounds were reduced, alkylated and in-gel digested with trypsin. $N$. chromatus showed two bands with 61.8 and 36.8, with the 61.8 $\mathrm{kDa}$ band been the only in the entire experiment with mass aside the standard $34-46 \mathrm{kDa}$. The isolated fractions were analyzed by LC-MS/MS to find hyaluronidase-like compounds. The activity was tested by turbidimetric assay and confirmed by SDS-PAGE and 2D-SDS-PAGE (14\%) zymograms with hyaluronic acid [66].

The study performed by Wilson et al. [41] revealed cytotoxic activity of $N$. chromatus venom against MCF-7 cells even without the presence of the polyamines $\mathrm{PA}_{366}$ and $\mathrm{PA}_{389}$, previously described as the primary focus of the study. The concentration utilized to perform the inhibition experiment against MCF-7 and $\mathrm{IC}_{50}$ were not show in the paper [41].

\section{Conclusion}

This review aims to highlight the pharmacological potential of chemical compounds from Brazilian Theraphosidae spider venoms. Thanks to the advance of science, poisons and venoms have become a great biotechnological template/tool for drug design, since they are a rich source in bioactive components with the most diverse molecular targets.

Despite the large number of described Theraphosidae spider species, about 185 , only 13 of them present any toxinological characterization report of crude venom and/or isolated compounds. Although the Brazilian Theraphosidae venom has a remarkable pharmacological potential, there is scarce research available on it. For a clearer understanding, species/ compound/activity is summarized in Table 3.

Among the countless challenges of modern medicine, we highlighted the microorganism resistance to conventional antibiotics, due to the indiscriminate use of them, and in addition, the dramatic decline of new antimicrobials development. A great example of the spiders' potential for drug discovery are the antimicrobial peptides or "low weight mass compounds" presented here that have shown activity against a broad spectrum of bacteria and fungi.

Gomesin, which was originally reported to have an antimicrobial activity, also demonstrated activity against melanoma cells. Similarly, mygalin, when incorporated into silver nanoparticles, increased its already described antimicrobial activity and also revealed antitumor activity. The discovery of alternatives for cancer therapies is desired, since chemotherapy involves the use of drugs to selectively destroy the tumor or limit its growth. However, the use of these cytotoxic agents has several side effects, such as bone marrow suppression, gastrointestinal lesions, nausea, in addition to the development of clinical resistance.

The ability to selectively inhibit ion channels or block receptors to paralyze prey shown by some venom chemical constituents can also be able to reduce chronic pain, or even be useful for the development of drugs that can help the treatment of neural diseases such as Alzheimer's, Parkinson's and seizures.

Table 3. Documented activities from Brazilian Theraphosidae venom compounds.

\begin{tabular}{|c|c|c|c|c|}
\hline Species & Compound & Activity & Target & Reference \\
\hline T. blondi & Crude venom & Neuromuscular blockage & $\begin{array}{l}\text { Mouse phrenic nerve- } \\
\text { diaphragm preparation }\end{array}$ & Fontana et al. [14] \\
\hline T. blondi & Crude venom & $\begin{array}{l}\text { A-type currents inhibition on } \\
\text { recombinant Kv } 4.2 \text { channels }\end{array}$ & $\begin{array}{l}\text { Recombinant C57/B16 } \\
\text { Recombinant HEK } 293\end{array}$ & Ebbinghaus et al. [15] \\
\hline T. blondi & k-theraphotoxin-Tb1a & $\begin{array}{l}\text { Inhibition of recombinant } \\
\text { Kv } 4.2 \text { channels } \\
\text { Slowed Kv } 4.2 \text { kinetics }\end{array}$ & $\begin{array}{l}\text { Recombinant C57/B16 } \\
\text { Recombinant HEK } 293\end{array}$ & Ebbinghaus et al. [15] \\
\hline T. apophysys & $\begin{array}{c}\text { TRTX-Tap1a } \\
\text { Recombinant TRTX-Tap1a }\end{array}$ & $\begin{array}{l}\text { Inhibitory activity on } \mathrm{Na}_{v} \\
\text { channels } \\
\text { Inhibitory activity on } \mathrm{Ca}_{\mathrm{v}} \\
\text { channels }\end{array}$ & $\begin{array}{l}\text { Recombinant C57/B16 } \\
\text { Recombinant HEK } 293\end{array}$ & Cardoso et al. [18] \\
\hline T. apophysys & $\begin{array}{c}\text { TRTX-Tap2a } \\
\text { Recombinant TRTX-Tap2a }\end{array}$ & $\begin{array}{l}\text { Inhibitory activity on } \mathrm{Na}_{\mathrm{v}} \\
\text { channels } \\
\text { Inhibitory activity on } \mathrm{Ca}_{\mathrm{v}} \\
\text { channels }\end{array}$ & $\begin{array}{l}\text { Recombinant C57/B16 } \\
\text { Recombinant HEK } 293\end{array}$ & Cardoso et al. [18] \\
\hline A. gomesiana & Venom peptidic fraction & Antimicrobial & $\begin{array}{l}\text { Gram-negative } \\
\text { Yeasts }\end{array}$ & Abreu et al. [20] \\
\hline A. gomesiana & Gomesin & Antimicrobial & $\begin{array}{c}\text { Gram-positive } \\
\text { Gram negative } \\
\text { Fungi }\end{array}$ & Silva et al. [21] \\
\hline A. gomesiana & Gomesin & Antitumoral & MM96L BRAF mutated cells & Ikonomopoulou et al. [23] \\
\hline A. gomesiana & $\begin{array}{l}\text { Acanthoscurrin-1 } \\
\text { Acanthoscurrin-2 }\end{array}$ & Antimicrobial & $\begin{array}{c}\text { Gram-negative } \\
\text { Yeasts }\end{array}$ & Lorenzini et al. [24] \\
\hline
\end{tabular}


Table 3. Cont.

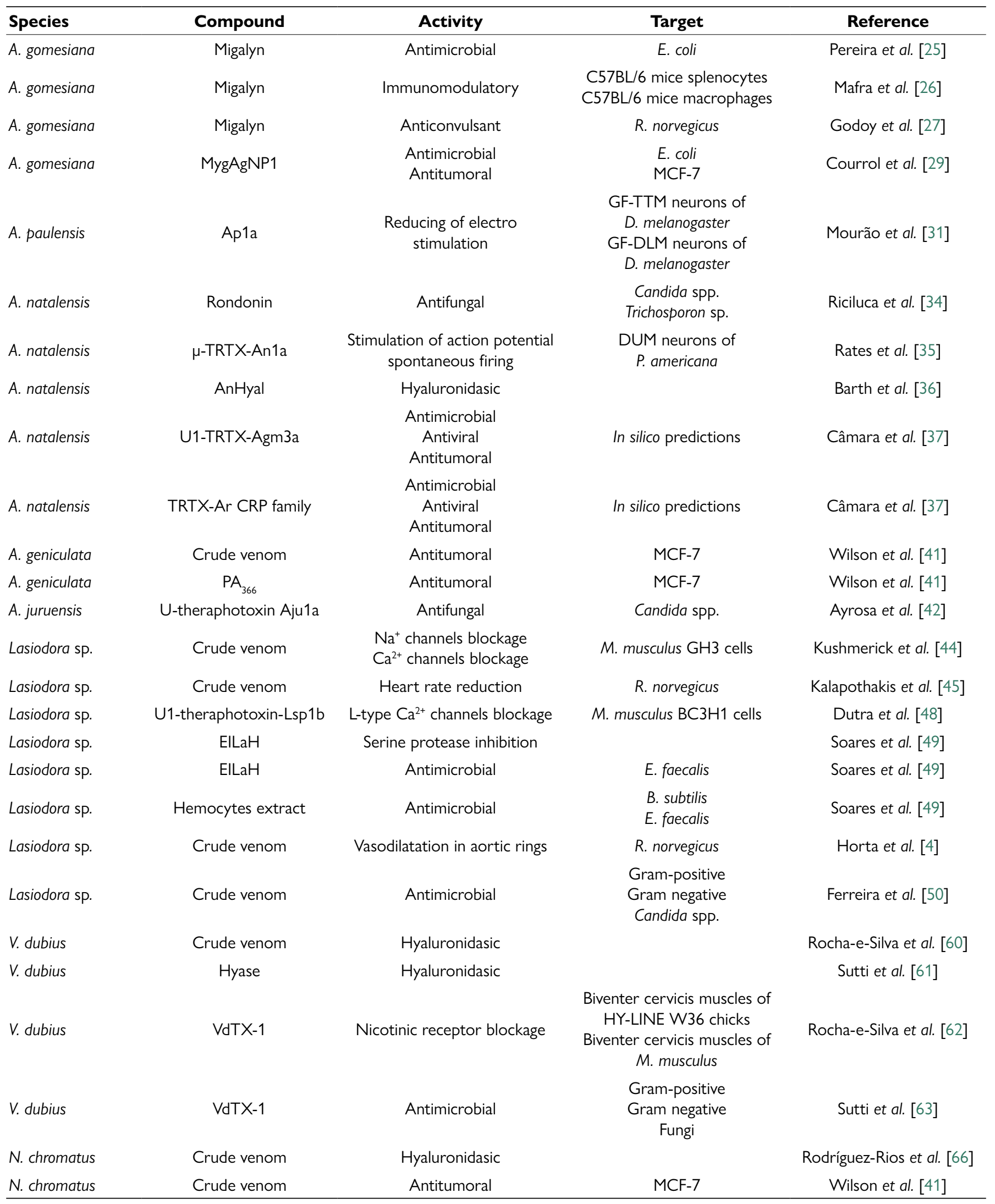


Concluding, Brazil is a giant in biodiversity, and spiders are truly natural pharmacological libraries. Both facts must motivate researchers and institutions for further studies in toxinological and conservation fields.

\section{Abbreviations}

2D BN/SDS-PAGE: two-dimensional blue native sodium dodecyl sulfate polyacrylamide gel electrophoresis; 2D-NMR: two-dimensional nuclear magnetic resonance; ADP: adenosine diphosphate; AFP: antifungal protein; AMP: adenosine monophosphate; ATCC: American Type Culture Collection; $\mathrm{Ca}_{\mathrm{v}}$ : voltage-dependent calcium channels; cDNA: complementary desoxyribonucleic acid; CFDA: carboxyfluorescein diacetate assay; CFU: colony forming units; COX: cytochrome-C oxidase; CRISP: cysteine-rich secretory proteins; CRP: cysteine-rich proteins; CZE: capillary zone electrophoresis; DAPI: 4',6-diamidino-2-phenylindole; DDH: disulfide directed $\beta$-hairpin; DHR: dihydrorhodamine hydrochloride; DUM: dorsal unpaired median neurons; $\mathrm{EC}_{50}$ : effective dose for 50\%; ELISA: enzyme linked immunosorbent assay; ESI-MS/ MS: electrospray ionization tandem mass spectrometry; ESIMS: electrospray ionization mass spectrometry; GF-DLM: giant fiber dorsal longitudinal motor neurons; GF-TTM: giant fiber tergo trochanteral motor neurons; $\mathrm{hNa}_{\mathrm{v}}$ channels: human voltage dependent sodium channels; $\mathrm{IC}_{50}$ : inhibitory concentration to $50 \%$ inhibition; IFN- $\gamma$ : interferon gamma; IgG: immunoglobulin G; IL-1 $\beta$ : interleukin 1 beta; iNOS: inducible nitric oxide synthase; $\mathrm{KCl}$ : potassium chloride; $\mathrm{K}_{\mathrm{v}}$ channels: voltage-dependent potassium channels; LC/ESI-MS: liquid chromatography/electrospray ionization mass spectrometry; LC/ ESI-QqTOFMS: liquid chromatography electrospray-ionization hybrid quadrupole time of flight mass spectrometer; LC-MS/ MS: liquid chromatography tandem mass spectrometry; LC-MS: liquid chromatography mass spectrometry; $\mathrm{LD}_{50}$ : lethal dose for 50\%; LMMF: low molecular mass fraction; L-NAME: Nvnitro-L-arginine methyl ester; L-NIL: L-N6-(1-iminoethyl)lysine dihydrochloride; LPS: lipopolysaccharide; MALDI-TOF/MS: matrix-assisted laser desorption/ionization time-of-flight mass spectrometry; mic: minimal inhibitory concentration; MS/MS: tandem mass spectrometry; MTT: microculture tetrazolium test; MudPIT: multidimensional protein identification technology; MygAgNPs: mygalin silver nanoparticles; nanoESI-QqTOFMS: nanoelectrospray ionization/hybrid quadrupole time-of-flight mass spectrometry; NFF: neonatal foreskin fibroblasts; NMDA: N-methyl-D-aspartate; PBMC: peripheral blood mononuclear cells; PCR: polymerase chain reaction; PI: propidium iodide; $\mathrm{PLA}_{2}$ : phospholipase A2; PTZ: pentylenetetrazole; Q-TOF/ MS: quadrupole/orthogonal acceleration time-of-flight mass spectrometry; reverse phase-high performance liquid chromatography; ROS: reactive oxygen species; SDS-PAGE: sodium dodecyl sulfate polyacrylamide gel electrophoresis; Th1: T helper 1; Th2: T helper 2; TNF a: tumor necrosis factor alpha; TRTXs: theraphotoxins; TTX: tetrodotoxin; UDMSE: Ultra Definition Mass Spectrometry ${ }^{\mathrm{E}}$.

\section{Acknowledgments}

Authors would like to give special thanks to Professor Paulo César Motta for all the support during research and allowing the use of photographs.

\section{Availability of data and materials}

Not applicable.

\section{Funding}

The present work was supported by the Coordination for the Improvement of Higher Education Personnel (CAPES) and the National Council for Scientific and Technological Development (CNPq).

\section{Competing interests}

The authors declare that they have no competing interests.

\section{Authors' contributions}

KWRM and LJLC performed the literature research and wrote the text. JOS, JSC, IAV, CJCS, ACMM and MSC wrote the text and carried out the revisions. ORPJ participated in research, writing and revision steps. All authors read and approved the final manuscript.

\section{Ethics approval}

Not applicable.

\section{Consent for publication}

Not applicable.

\section{References}

1. Escoubas P, Rash L. Tarantulas: eight-legged pharmacists and combinatorial chemists. Toxicon. 2004 Apr;43(5):555-74.

2. World Spider Catalog. World Spider Catalog. Version 21.5. Nat HistMus Bern. Cited on Nov 20, 2020.

3. Motta P, Bertani R, Diniz I, Marinho-Filho J, Machado R, Cavalcanti R. Registros de aranhas (Araneae: Araneidae, Theraphosidae) e escorpiões (Scorpiones) do Cerrado. p. 149-85. 2012.

4. Horta C, Rezende B, Oliveira-Mendes B, Carmo A, Capettini L, Silva JF, Gomes MT, Chávez-Olórtegui C, Bravo CES, Lemos VS, Kalapothakis E. ADP is a vasodilator component from Lasiodora sp. mygalomorph spider venom. Toxicon. 2013 Sep;72:102-12.

5. Jackson H, Parks TN. Spider toxins: recent applications in neurobiology. Annu Rev Neurosci. 1989;12:405-14.

6. Söderhäll K, Smith VJ. Separation of the haemocyte populations of Carcinusmaenas and other marine decapods, and prophenoloxidase distribution. Dev Comp Immunol. Spring 1983;7(2):229-39.

7. Escoubas P, Diochot S, Corzo G. Structure and pharmacology of spider venom neurotoxins. Biochimie. Sep-Oct 2000;82(9-10):893-907.

8. Vassilevski AA, Kozlov SA, Grishin EV. Molecular diversity of spider venom. Biochemistry (Mosc). 2009 Dec;74(13):1505-34.

9. Corzo G, Villegas E, Gómez-Lagunas F, Possani LD, Belokoneva OS, Nakajima T. Oxyopinins, large amphipathic peptides isolated from the venom of the wolf spider Oxyopes kitabensis with cytolytic properties and positive insecticidal cooperativity with spider neurotoxins. J Biol Chem. 2002 Jun 28;277(26):23627-37. 
10. Estrada G, Villegas E, Corzo G. Spider venoms: a rich source of acylpolyamines and peptides as new leads for CNS drugs. Nat Prod Rep. 2007 Feb;24(1):145-61.

11. Liberati A, Altman DG, Tetzlaff J, Mulrow C, Gøtzsche PC, loannidis JP, Clarke M, Devereaux PJ, Kleijnen J, Moher D. The PRISMA statement for reporting systematic reviews and meta-analyses of studies that evaluate health care interventions: explanation and elaboration. J Clin Epidemiol. 2009 Jul 21;62(10):e1-e34.

12. Striffler BF. Life history of Goliath Birdeaters-Theraphosa apophysis and Theraphosa blondi (Araneae, Theraphosidae, Theraphosinae). J Br Tarantula Soc. 2005;21(1):26-33.

13. Nyffeler M, Lapinski W, Snyder A, Birkhofer K. Spiders feeding on earthworms revisited: consumption of giant earthworms in the tropics. J Arachnol. 2017;45(2):242-7.

14. Fontana $M$, Lucas $H$, Vital Brazil $O$. Neuromuscular blocking action of the Theraphosa blondii spider venom. J Venom Anim Toxins. 2002;8(2):316-23. https://doi.org/10.1590/S0104-79302002000200010.

15. Ebbinghaus J, Legros C, Nolting A, Guette C, Celerier ML, Pongs O, Bahring R. Modulation of Kv4. 2 channels by a peptide isolated from the venom of the giant bird-eating tarantula Theraphosa leblondi. Toxicon. 2004 Jun 15;43(8):923-32.

16. Legros C, Célérier ML, Henry M, Guette C. Nanospray analysis of the venom of the tarantula Theraphosa leblondi: a powerful method for direct venom mass fingerprinting and toxin sequencing. Rapid Commun Mass Spectrom. 2004;18(10):1024-32.

17. Tinter A. Eine neue Vogelspinne aus Venezuela Pseudotheraphosa apophysis n. gen. n. sp. Araneae: Theraphosidae: Theraphosinae), Arachnol Anzeiger. 1991;16:6-10.

18. Cardoso FC, Castro J, Grundy L, Schober G, Garcia-Caraballo S, Zhao T, Herzig V, King GF, Brierley SM, Lewis RJ. A spider-venom peptide with multitarget activity on sodium and calcium channels alleviates chronic visceral pain in a model of irritable bowel syndrome. Pain. 2021 Feb 1;162(2):569-81.

19. Miranda A, Miranda MTM, Jouvensal L, Vovelle F, Bulet P, Daffre SG. A powerful antimicrobial peptide isolated from the Brazilian tarantula spider Acanthoscurria gomesiana. In Animal Toxins: State of the Art Perspectives in Health and Biotechnology. p. 227-47. 2009.

20. Abreu TF, Sumitomo BN, Nishiyama Jr MY, Oliveira UC, Souza GH, Kitano ES, Zelanis A, Serrano SMT, Junqueira-de-Azevedo I, Silva Jr PI Tashima AK. Peptidomics of Acanthoscurria gomesiana spider venom reveals new toxins with potential antimicrobial activity. JProteomics. 2017 Jan 16;151:232-42.

21. Silva PI, Daffre S, Bulet P. Isolation and characterization of gomesin, an 18-residue cysteine-rich defense peptide from the spider Acanthoscurria gomesiana hemocytes with sequence similarities to horseshoe crab antimicrobial peptides of the tachyplesin family. J Biol Chem. 2000 Oct 27; 275(43):33464-70.

22. Mandard N, Bulet P, Caille A, Daffre S, Vovelle F. The solution structure of gomesin, an antimicrobial cysteine-rich peptide from the spider. Eur J Biochem. 2002 Feb 20;269(4):1190-8.

23. Ikonomopoulou MP, Fernandez-Rojo MA, Pineda SS, Cabezas-Sainz P, Winnen B, Morales RA, Brust A, Sánchez L, Alewood PF, Ramm GA, Miles JJ, King GF. Gomesin inhibits melanoma growth by manipulating key signaling cascades that control cell death and proliferation. Sci Rep. 2018 Aug 1;8(1):11519.

24. Lorenzini DM, da Silva Jr PI, Fogaça AC, Bulet P, Daffre S. Acanthoscurrin: a novel glycine-rich antimicrobial peptide constitutively expressed in the hemocytes of the spider Acanthoscurria gomesiana. Dev Comp Immunol. 2003 Oct;27(9):781-91.

25. Pereira LS, Silva Jr PI, Miranda MTM, Almeida IC, Naoki H, Konno K, Daffre S. Structural and biological characterization of one antibacterial acylpolyamine isolated from the hemocytes of the spider Acanthocurria gomesiana. Biochem Biophys Res Commun. 2007 Jan 26;352(4):953-9.

26. Mafra DG, da Silva Jr PI, Galhardo CS, Nassar R, Daffre S, Sato MN, Borges MM. The spider acylpolyamine Mygalin is a potent modulator of innate immune responses. Cell Immunol. 2012 Jan-Feb;275(1-2):5-11.
27. Godoy DL, Liberato LJ, Silva Jr IP, Santos WF. Mygalin: A New Anticonvulsant Polyamine in Acute Seizure Model and Neuroethological Schedule. Cent Nerv Syst Agents Med Chem. 2013 Jun;13(2):122-31.

28. Espinoza-Culupú A, Mendes E, Vitorino HA, da Silva Jr PI, Borges MM. Mygalin: An acylpolyamine with bactericidal activity. Front Microbiol. 2020 Jan 10;10:2928.

29. Courrol LC, Espinoza-Culupú A, da Silva PI, de Oliveira Gonçalves K, de Oliveira Silva FR, Borges MM. Antibacterial and antitumoral activities of the spider acylpolyamine Mygalin silver nanoparticles. BioNanoScience. 2020 Apr 17;10(2):463-72.

30. Lucas SM, Paula FdS, Gonzalez Filho HM, Brescovit AD. Redescription and new distribution records of Acanthoscurria paulensis (Araneae: Mygalomorphae: Theraphosidae). Zoologia (Curitiba). 2010 Aug;27(4):563-8.

31. Mourão CBF, Oliveira FN, e Carvalho AC, Arenas CJ, Duque HM, Gonçalves JC, Macedo JKA, Galante P, Schwartz CA, Mortari MR, Santos MFMA, Schwartz EF. Venomic and pharmacological activity of Acanthoscurria paulensis (Theraphosidae) spider venom. Toxicon. 2013 Jan;61:129-38.

32. Mourão CB, Heghinian MD, Barbosa EA, Marí F, Bloch Jr C, Restano-Cassulini $R$, Possani LD, Schwartz EF. Characterization of a novel peptide toxin from Acanthoscurria paulensis spider venom: a distinct cysteine assignment to the HWTX-II family. Biochemistry. 2013 Apr 9;52(14):2440-52.

33. Lucas SM, Gonzalez Filho HM, Paula FdS, Gabriel R, Brescovit AD. Redescription and new distribution records of Acanthoscurria natalensis (Araneae: Mygalomorphae: Theraphosidae). Zoologia (Curitiba). 2011;28(4):525-30.

34. Riciluca K, Sayegh R, Melo RLd, Silva Jr P. Rondonin an antifungal peptide from spider (Acanthoscurria rondoniae) haemolymph. Results Immunol. 2012 Apr;2:66-71.

35. Rates B, Prates MV, Verano-Braga T, Da Rocha ÂP, Roepstorff P, Borges CL, Lapied B, Murillo L, Pimenta AMC, Biondi I, De Lima ME. $\mu$-Theraphotoxin-An1a: primary structure determination and assessment of the pharmacological activity of a promiscuous anti-insect toxin from the venom of the tarantula Acanthoscurria natalensis (Mygalomorphae, Theraphosidae). Toxicon. 2013;70:123-34.

36. Barth T, Mandacaru SC, Charneau S, de Souza MV, Ricart CAO, Noronha EF, Souza AA, Freitas SM, Roepstorff P, Fontes W, Castro MS, Pires Jr OR. Biochemical and structural characterization of a protein complex containing a hyaluronidase and a CRISP-like protein isolated from the venom of the spider Acanthoscurria natalensis. J Proteomics. 2019 Feb 10;192:102-13.

37. Câmara GA, Nishiyama-Jr MY, Kitano ES, Oliveira UC, Silva Jr PId, Junqueira-de-Azevedo IL, Tashima AK. A multiomics approach unravels new toxins with possible in silico antimicrobial, antiviral, and antitumoral activities in the venom of Acanthoscurria rondoniae. Front Pharmacol. 2020 Jul 17;11:1075.

38. Paula FdS, Gabriel R, Indicatti RP, Brescovit AD, Lucas SM. On the Brazilian Amazonian species of Acanthoscurria (Araneae: Theraphosidae). Zoologia (Curitiba). 2014 Feb;31(1):63-80.

39. Sanggaard KW, Bechsgaard JS, Fang X, Duan J, Dyrlund TF, Gupta V, Jiang $X$, Cheng L, Fan D, Feng Y, Han L, Huang Z, Wu Z, Liao L, Settepani V, Thogersen IB, Vanthournout B, Wang T, Zhu Y, Funch P, Enghild JJ, Schauser L, Andersen SU, Villesen P, Schierup MH, Bilde T, Wang J. Spider genomes provide insight into composition and evolution of venom and silk. Nat Commun. 2014 May 6;5(1):1-12.

40. Walter A, Bechsgaard J, Scavenius C, Dyrlund TS, Sanggaard KW, Enghild $\mathrm{J}$, Bilde T. Characterisation of protein families in spider digestive fluids and their role in extra-oral digestion. Bmc Genomics. 2017 Aug 10;18(1):600.

41. Wilson D, Boyle GM, Mclntyre L, Nolan MJ, Parsons PG, Smith JJ, Tribolet L, Loukas A, Liddell MJ, Rash LD, Daly NL. The aromatic head group of spider toxin polyamines influences toxicity to cancer cells. Toxins (Basel). 2017 Nov;9(11):346.

42. Ayroza G, Candido Ferreira IL, Sayegh RSR, Tashima AK, Da Silva Junior PI. Juruin: an antifungal peptide from the venom of the Amazonian Pink Toe spider, Avicularia juruensis, which contains the inhibitory cystine knot motif. Front Microbiol. 2012;3:324. 
43. Fukushima CS, Bertani R. Taxonomic revision and cladistic analysis of Avicularia Lamarck, 1818 (Araneae, Theraphosidae, Aviculariinae) with description of three new aviculariine genera. ZooKeys. 2017(659):1.

44. Kushmerick C, de Carvalho FM, De Maria M, Massensini A, Romano-Silva M, Gomez M, Kalapothakis E, Prado MA. Effects of a Lasiodora spider venom on $\mathrm{Ca}^{2+}$ and $\mathrm{Na}^{+}$channels. Toxicon. 2001 Jul;39(7):991-1002.

45. Kalapothakis E, Kushmerick C, Gusmão DR, Favaron GO, Ferreira AJ, Gomez MV, Almeida AP. Effects of the venom of a Mygalomorph spider (Lasiodora sp.) on the isolated rat heart. Toxicon. 2003 Jan;41(1):23-8.

46. Vieira A, Moura M, Babá E, Chávez-Olórtegui C, Kalapothakis E, Castro I. Molecular cloning of toxins expressed by the venom gland of Lasiodora sp. Toxicon. 2004 Dec 15;44(8):949-52.

47. UniProt KB Database. Lasiodora sp. in UniProtKB [cited 2021 Oct 14]. Available from: https://www.uniprot.org/uniprot/?query=lasiodora+sp\&sort=score

48. Dutra AA, Sousa LO, Resende RR, Brandão RL, Kalapothakis E, Castro IM. Expression and characterization of $L T \times 2$, a neurotoxin from Lasiodora sp. effecting on calcium channels. Peptides. 2008 Sep;29(9):1505-13.

49. Soares T, Ferreira FRB, Gomes FS, Coelho LCBB, Torquato RJS, Napoleão TH, Cavalcanti MSM, Tanaka AS, Paiva PMG. The first serine protease inhibitor from Lasiodora sp. (Araneae: Theraphosidae) hemocytes. Proc Biochem. 2011;46(12):2317-21.

50. Ferreira FRB, da Silva PM, Soares T, Machado LG, de Araújo LCC, da Silva TG, Mello GSV, Pitta MGR, Melo MJB, Pontual EV, Zingali RB, Napoleão TH, Paiva PMG. Evaluation of antimicrobial, cytotoxic, and hemolytic activities from venom of the spider Lasiodora sp. Toxicon. 2016 Nov;122:119-26.

51. EoL: The Enciclopedia of Life. Brazilian Salmon Pink Tarantula Lasiodora parahybana Mello-Leitão 1917 [cited 2020 Nov 24]. Available from: https:// eol.org/pages/1182110.

52. Escoubas P, Célérier M, Romi-Lebrun R, Nakajima T. Two novel peptide neurotoxins from the venom on the tarantula Lasiodora parahybana. Toxicon. 1997;35(6):805-6.

53. Escoubas P, Corzo G, Whiteley BJ, Célérier ML, Nakajima T. Matrixassisted laser desorption/ionization time-of-flight mass spectrometry and high-performance liquid chromatography study of quantitative and qualitative variation in tarantula spider venoms. Rapid Commun Mass Spectrom. 2002;16(5):403-13.

54. Guette C, Legros C, Tournois G, Goyffon M, Célérier ML. Peptide profiling by matrix-assisted laser desorption/ionisation time-of-flight mass spectrometry of the Lasiodora parahybana tarantula venom gland. Toxicon. 2006 May;47(6):640-9.
55. Bücherl W. Estudos sobre a biologia e a sistemática do gênero Grammostola Simon, 1892: Instituto Butantan; 1951.

56. Borges MH, Figueiredo SG, Leprevost FV, De Lima ME, Cordeiro MdN, Diniz MRV, Moresco J, Carvalho PC, Yates JR. Venomous extract protein profile of Brazilian tarantula Grammostola iheringi: searching for potential biotechnological applications. J Proteomics. 2016 Mar 16;136:35-47.

57. Mello L. XXXV.-On the genus Grammostola, Simon. Ann Mag Nat Hist. 1921;7(40):293-305.

58. Escoubas P, Whiteley BJ, Kristensen CP, Célérier M-L, Corzo G, Nakajima T. Multidimensional peptide fingerprinting by high performance liquid chromatography, capillary zone electrophoresis and matrix-assisted laser desorption/ionization time-of-flight mass spectrometry for the identification of tarantula venom samples. Rapid Commun Mass Spectrom. 1998;12(16):1075-84.

59. Bertani R. Revision, cladistic analysis, and zoogeography of Vitalius, Nhandu, and Proshapalopus; with notes on other Theraphosine Genera (Araneae, Theraphosidae). Arq Zool. 2001;36(3):265-356.

60. Rocha-e-Silva TA, Sutti R, Hyslop S. Milking and partial characterization of venom from the Brazilian spider Vitalius dubius (Theraphosidae). Toxicon. 2009 Jan;53(1):153-61.

61. Sutti R, Tamascia ML, Hyslop S, Rocha-e-Silva TAA. Purification and characterization of a hyaluronidase from venom of the spider Vitalius dubius (Araneae, Theraphosidae). J Venom Anim Toxins incl Trop Dis. 2014;20(1):2. https://doi.org/10.1186/1678-9199-20-2.

62. Rocha-e-Silva TA, Rostelato-Ferreira S, Leite GB, da Silva Jr PI, Hyslop S, Rodrigues-Simioni L. VdTX-1, a reversible nicotinic receptor antagonist isolated from venom of the spider Vitalius dubius (Theraphosidae). Toxicon. 2013 Aug;70:135-41.

63. Sutti R, Rosa BB, Wunderlich B, da Silva Junior PI. Antimicrobial activity of the toxin VdTX-I from the spider Vitalius dubius (Araneae, Theraphosidae). Biochem Biophys Rep. 2015 Sep 28;4:324-8.

64. Rocha-e-Silva TA, Linardi A, Antunes E, Hyslop S. Pharmacological characterization of the edema caused by Vitalius dubius (Theraphosidae, Mygalomorphae) spider venom in rats. J Pharmacol Exp Ther. 2016 Jan;356(1):13-9.

65. Schultz SA, Schultz MJ. The Tarantula Keeper's Guide: Barron's Educational Series; 2009.

66. Rodríguez-Rios L, Díaz-Peña LF, Lazcano-Pérez F, Arreguín-Espinosa R, Rojas-Molina A, García-Arredondo A. Hyaluronidase-like enzymes are a frequent component of venoms from theraphosid spiders. Toxicon. 2017 Sep 15;136:34-43. 